$$
\begin{array}{r}
\text { ADORN } \\
\text { CONTAS E PINGEN } \\
\text { NA FOZ DO RIO AMAZO } \\
\text { ESTUDO DE CASO } \\
\text { SÍTIO CURIAÚ MIR }
\end{array}
$$




\section{ADORNOS, CONTAS E PINGENTES NA FOZ DO RIO AMAZONAS: ESTUDO DE CASO DO SÍTIO CURIAÚ MIRIM I}

\section{AVELINO GAMBIM JÚNIOR}

UNIVERSIDADE FEDERAL DO AMAPÁ, BRASIL

\section{CLÁUDIA RODRIGUES CARVALHO}

UNIVERSIDADE FEDERAL RIO DE JANEIRO, BRASIL

\section{JOÃO DARCY DE MOURA SALDANHA}

UNIVERSIDADE DE SÃO PAULO, BRASIL

$$
\text { MARIANA PETRY CABRAL }
$$




\title{
ADORNOS, CONTAS E PINGENTES NA FOZ DO RIO AMA- ZONAS: ESTUDO DE CASO DO SÍTIO CURIAÚ MIRIM I
}

\section{Resumo}

Este artigo tem como objetivo oferecer uma possibilidade explanatória na interpretação de adornos arqueologicamente contextualizados através do conceito de corporalidade ameríndia e noções de pessoa. Neste intuito trago como estudo de caso o sítio Curiaú Mirim I, datado por volta do século X ao XVII AD. Esse sítio contém evidências de áreas de sepultamentos humanos e feições e estruturas possivelmente domésticas. Através da observação de adornos encontrados em contextos funerários das Guianas e foz do rio Amazonas procurou-se, inspirado nas ideias da corporalidade ameríndia da etnologia amazônica, propor interpretações que dessem conta de significados como a construção de sociabilidades e identidades em vida e na morte até a corporalidade pós-morte vistas numa história indígena de longa duração.

Palavras-Chave: Corporalidade ameríndia, sepultamentos, ornamentos, história de longa duração.

\section{ORNAMENTS, BEADS AND PENDANTS AT THE MOUTH OF THE AMAZON RIVER: CASE STUDY OF CURIAÚ MIRIM I SITE}

\begin{abstract}
This paper aims to offer an explanatorily possibility in the interpretation of archaeological contextualized ornaments through the concept of Amerindian corporality and notions of person. In this regard, I bring as a case study the Curiaú Mirim I site, dating back to the 10 th to 17 th centuries AD. This site contains evidence of areas of human burial and possibly domestic features and structures. Through the observation of ornaments found in burial contexts in the Guianas and the mouth of the Amazon River, it was sought to propose, inspired by the Amerindian corporality ideas of the Amazonian ethnology, interpretations that account for meanings such as the construction of sociabilities and identities in life and in death until the corporality after death seen in a long indigenous history duration.
\end{abstract}

Keywords: Amerindian corporality, burials, ornaments, long-term history. 


\section{ADORNOS, CUENTAS Y PENDIENTES EN LA DESEMBOCA- DURA DEL RIO AMAZONAS: ESTUDIO DE CASO DEL SITIO CURIAÚ MIRIM I}

\section{Resumen}

Este artículo tiene como objetivo ofrecer una posibilidad explicativa en la interpretación de adornos arqueológicamente contextualizados, a través del concepto de corporalidad amerindia y de las nociones de persona. Con este propósito, pongo como estudio de caso el sitio Curiaú Mirim I, datado cerca del siglo X al XVII AD. Este sitio posee evidencias de áreas de sepultura humana, así como de aspectos y estructuras posiblemente domésticas. A través de la observación de adornos encontrados en contextos funerarios de las Guyanas y de la desembocadura del rio Amazonas, se buscó, inspirado en las ideas de la corporalidad amerindia de la etnología amazónica, proponer interpretaciones que den cuenta de algunos significados sobre la construcción de sociabilidades y de identidades en vida y en muerte, hasta la corporalidad post mortem, vistas en una historia indígena de larga duración.

Palabras Clave: Corporalidad amerindia, sepulturas, ornamentos, historia de larga duración

Avelino Gambim Júnior

avgambimjunior@gmail.com

Cláudia Rodrigues Carvalho

claudia@mn.ufrj.br

João Darcy de Moura Saldanha jodanha@gmail.com

Mariana Petry Cabral

nanacabral75@gmail.com 


\section{INTRODUÇÃO}

A decoração corporal com ornamentos como, por exemplo, pulseiras e colares de contas, confeccionados a partir de diferentes tipos de matérias primas, são recorrentes em sociedades indígenas atuais (Lagrou 2012). Tem sido igualmente registrada através de documentações primárias de cronistas e viajantes que atestam as impressões do colonizador europeu em relação ao uso de adornos desde o século XVI na região amazônica (Roth 1924).

No período da América Antiga (anterior ao processo de colonização europeu) e de contato, o registro arqueológico de prováveis adornos tem sido encontrado em uma ampla área geográfica e aqui exemplificados para a Amazônia pelo escudo das guianas e a foz do rio Amazonas (Bel 2014; Nimuendaju 2004; Meggers \& Evans 1957). É importante ressaltar que, na maioria dos casos, estes adornos aparecem principalmente inseridos em contextos funerários.

Quanto ao registro de contextos mortuários, além de objetos interpretados como prováveis adornos, há evidências de urnas funerárias antropomorfas com apliques cerâmicos representando desde diademas, pulseiras, até tornozeleiras e outros adereços (Saldanha \& Cabral 2012; Gambim Júnior 2016; Guapindaia 2001; Barreto 2008) demonstrando a recorrência dos adornos corporais.

Já é amplamente aceito na etnologia ameríndia o caráter e importância da corporalidade na constituição da sociabilidade de muitos povos ameríndios amazônicos na atualidade (Seeger et al. 1979; Rival 2005).

A ideia de um corpo que é construído e submetido às transformações, às imposições e aos regramentos encontra terreno fértil nas cosmologias ameríndias (Lagrou 2012), onde o último suspiro/cessação das funções fisiológicas não é o fim, onde o morto pode afetar os vivos e onde os vivos celebram os mortos, de certa forma também os transformando e transformando a comunidade vivente dentro dessa mesma lógica, o que traz consequências importantes a serem pensadas na arqueologia (Gambim Júnior 2016).

Não é o intuito aqui realizar analogias etnográficas diretas, muito menos procurar identificar etnias no registro arqueológico, de modo que se procura por interpretações mais generalistas, pensadas como possibilidades.

Isso não significa que se deva recair em generalizações simplistas quanto às cosmologias indígenas relacionadas ao "índio genérico" (Ramos 2012), e muito menos defender uma visão homogênea dos povos indígenas na Amazônia antiga (Schaan 2014:30).

A existência de modelos ontológicos relacionados às sociedades indígenas amazônicas, como o perspectivismo ameríndio (Viveiros de Castro 1996, 2001) ou mesmo o animismo (Descolá 2005) têm implicações importantes na etnologia ameríndia, porém isso não significa que se procure "enxergar" tais modelos no passado arqueológico.

Esses modelos teóricos são amplamente utilizados na interpretação de sociedades ameríndias contemporâne- 
as e dizem respeito não somente aos corpos humanos, mas também aos corpos não humanos, o que levou ao aprofundamento desses modelos ontológicos principalmente quanto a discussões em torno das materialidades e do lado oculto das coisas (Barcelos Neto 2008; Lagrou 2007; Van Velthen 2007; Santos Granero 2009).

Em relação aos questionamentos quanto a estas diferentes ontologias, as mesmas são de extrema importância, pelo menos quanto a provocações que inspiram a pensar igualmente na construção dos corpos após a morte, na agência dos mortos e das coisas dos mortos em relação aos vivos e quais suas implicações na explanação e interpretação do registro arqueológico devidamente contextualizado.

$\mathrm{Na}$ verdade o que busco aqui é retornar a um ponto anterior à formulação desses modelos onde foi defendida a importância da corporalidade e noções de pessoa nessas sociedades como lócus das relações sociais, devido ao rendimento interpretativo que tal idéia possibilita aos dados coletados pelas (os) arqueólogas (a)s, exemplificados aqui pelos sepultamentos citados e o estudo de caso aqui apresentado.

Admite-se que a cultura nunca é estática, desse modo, longe de desconsiderar os processos históricos de mudanças culturais e rupturas pelas quais diversas sociedades indígenas têm passado na história de longa duração (Braudel 1965), deve-se enfatizar que são levadas em conta as particularidades que cada sociedade certamente possuiu e possuí. Porém leva-se em consideração a possibilidade de algumas continuidades e alguns traços culturais talvez compartilhados entre uma ampla região geográfica, perspectiva que têm sido amplamente utilizada e defendida na arqueologia (Hodder 1987).

A escolha dos sítios aqui referidos deu-se por conta da disponibilidade de dados alusivos a contas em contextos fechados específicos como os sepultamentos, que por este mesmo motivo podem ser relacionados com o sítio Curiaú Mirim I, aqui apresentado como estudo de caso e por se prestarem a proposta de discussão deste artigo. Nesse sentido, esses sítios estão temporalmente delimitados entre o século $\mathrm{X}$ até o século XIX $\mathrm{AD}$, no desígnio de mostrar a profundidade temporal que tais contas e outros tipos de adornos têm sido registrados.

Ao pensarmos no papel da cultura material em relação aos processos históricos de rupturas e continuidades, no registro arqueológico é possível observar em algumas recorrências e possíveis permanências no uso dos adornos corporais nas sociedades indígenas, como já foi demonstrado (Scaramelli \& Scaramelli 2005) para contextos das Guianas e em especial na Venezuela.

Ao admitir como possibilidade a centralidade do corpo como modelo teórico é possível interpretar o sítio arqueológico Curiaú Mirim I, através dos sepultamentos centrados nos corpos depositados. Desse modo dar-se-á primazia ao corpo (humano1), já que este sítio foi pensado exatamente por meio da análise esquelética nos sepultamentos, diga- 
-se, através de osteobiografias (Stodder \& Palkovich 2012; DiGangi \& Moore 2013), da arqueotanatologia (Roksandic 2002; Duday 2006) e da bioarqueolgia social (Sofaer 2006; Agarwall \& Glencross 2011) que leva em consideração aspectos da Teoria Social e por consequência os aspectos contextuais que foram levantados no estudo do sítio, neste caso as contas e adornos registrados ${ }^{2}$.

Longe de ser uma redução da extensão do que o corpo realmente pode ter significado para sociedades amazônicas antigas, assim como é o corpo (humano e não humano) para muitas sociedades ameríndias atuais3 busca-se principalmente através do corpo (restos esqueléticos humanos) mostrar a relevância da corporalidade através de seus acompanhamentos, sejam as urnas funerárias antropomorfas, seja os prováveis adornos corporais depositados junto aos mortos.

De modo a reforçar esta interpretação são citados alguns exemplos de documentação de relatos de cronistas e viajantes desde o século XVI até o século XX, assim como algumas etnografias já do século XX em diante para o território amazônico que tem registrado a ocorrência de adornos em diversas sociedades ameríndias, assim como o modo que estes cronistas e viajantes compreenderam o universo material daqueles povos que tiveram contato, fontes de inspiração no entendimento do contexto funerário do sítio Curiaú Mirim I.

\section{ADORNOS, CORPORALIDADE E NOÇÃO DE PESSOA}

Um dos marcos teóricos utilizados até hoje e amplamente aceitos pela etnologia ameríndia com possibilidades de implicações interpretativas ao registro arqueológico, diz respeito à noção de construção de corpos na Amazônia e as noções de pessoa na América Indígena que merecem atenção especial.

Admite-se o simbolismo corporal como linguagem básica de muitos grupos sul-americanos entendidas como essencialmente "fluidas, flexíveis e abertas à manipulação individual” (Seeger et al. 1979) onde o corpo é o locus das sociabilidades em articulação com o espaço e o tempo social.

O corpo desse modo é visto como um instrumento que profere significados sociais e cosmológicos e não apenas o sustentáculo de identidades e papéis sociais, mas como "uma matriz de símbolos e um objeto de pensamento, como um instrumento, articulando significações sociais e cosmológicas" (Segger et al. 1979). A partir desta abordagem, observou-se a ideia de um corpo constantemente construído e submetido a constantes processos intencionais e periódicos de fabricação (Viveiros de Castro 1979).

Dentro desta perspectiva, o corpo não pode ser visto como um mero "sinônimo de fisiologia distintiva ou anatomia característica, mas um conjunto de maneiras ou modos de ser que constituem um habitus" (Viveiros de Castro 2002:380).

$\mathrm{Na}$ etnologia ameríndia esta ideia de construção e transformação dos cor- 
pos, onde as pessoas são produzidas, grupos sociais são designados e diferenças são criadas, é tamanha que ao se negar essa noção de corporalidade a própria sociabilidade amazônica não pode ser completamente compreendida (Rival 2005).

Desse modo, a partir dessa premissa etnólogas (os) de campo passaram a considerar o mundo artefatual e sua relação com a construção das pessoas e de grupos sociais, desse modo o "estudo em profundidade do mundo artefatual que participa da fabricação do corpo ameríndio lança nova luz sobre conceitos ameríndios de corporalidade e de pessoa" (Lagrou 2012:21).

É importante ressaltar que essa ideia da construção dos corpos e noções de pessoa, perpassa não apenas os corpos "humanos", mas também os corpos "não humanos", e suas capacidades agentivas, já que essa corporalidade também se aplica, por exemplo, aos animais, aos espíritos e aos objetos, dentro do que se têm chamado de "virada ontológica" (Sá Júnior 2014) desenvolvendo-se posteriormente no animismo (Descolá 2005) e perspectivismo (Viveiros de Castro 2002).

Tais "viradas ontológicas" não ficam incólumes de críticas quanto aos seus usos em sociedades contemporâneas, mas é impossível não concordar que têm quebrado paradigmas dentro da antropologia ameríndia (Sá Júnior 2014) e por este motivo são mencionados aqui, já que boa parte das interpretações realizadas neste artigo, com suas devidas ponderações, leva em conside- ração a possibilidade de diferentes estatutos ontológicos.

Não se deve esquecer que os corpos amazônicos, segundo Rival (2005) são cronicamente instáveis e sujeitos a transformações, de modo que não devemos nos centrar somente ao universo que nós, não indígenas, concebemos como humanos, mas diferentes tipos de seres onde tal transformação e instabilidade são proeminentes (Rival 2005:460).

Ao nos voltarmos a estas reflexões em relação à corporalidade o que temos é um entrelaçamento entre diferentes seres, sejam eles humanos ou não humanos, na "fabricação de um corpo com capacidade agentiva e sua decoração exterior e interior”. (Lagrou 2012), neste caso, aplicando-se esse conceito ao sitio aqui estudado, consideramos os corpos humanos (esqueletos) e outros tipos de corpos não humanos, como os mortos e artefatos.

Depreende-se que a corporalidade é realizada através de ritos de passagem, exposição dos corpos, em reclusões e enfeites corporais que podem ser entendidos através da noção de habitus de Pierre Bourdieu (1977) materializada arqueologicamente por meio de gestos cerimoniais e funerários, ornamentos no interior das urnas e vestimentas/ornamentações e decorações nas urnas antropomorfas, seja por meio de modificações corporais.

Em relação aos métodos arqueológicos, esqueletos humanos acompanhados de suas ornamentações perpassam noções de gênero, idade e envelhecimento/amadurecimento (Sofaer 2006) 
entendidos no entrelaçamento das coisas com pessoas e das coisas com as coisas dando sentido a cultura material (Hodder 2012) de modo que o próprio corpo e não somente os objetos que os acompanham sejam pensados como uma forma especial de cultura material, não somente na manifestação da morte pelos enlutados, mas do corpo como uma cultura material em vida.

Desse modo, no intuito de refletir sobre esses questionamentos exponho aqui alguns exemplos dos adornos corporais de contextos arqueológicos funerários para as Guianas e Foz do Rio Amazonas, procurando de forma sucinta mostrar o contexto onde foram encontrados.

\section{ADORNOS E SEPULTAMENTOS NAS GUIANAS E FOZ DO AMAZONAS}

No sítio Awala-Yalimapo, onde hoje é a Guiana Francesa, cujas datações obtidas o situam dentro do século XI ao XIII AD, foram identificados sepultamentos secundários em urnas e sepultamentos primários em fossas, sendo indicado que se tratava de um contexto com possível estratificação social (Coutet et al. 2014:30-31). Dentro de uma das urnas foram identificadas contas de ossos associados a restos esqueléticos de dois indivíduos adultos e um infante 3 (Coutet et al. 2014). Como acompanhamento interno junto à urna, foram registradas contas de ossos (Coutet et al. 2014).

Em uma das fossas funerárias foram identificadas várias contas de conchas, além de um vaso com apliques zoo- morfos e fragmentos cerâmicos correspondentes a três vasos, bem como dois machados polidos em rochas verdes (Coutet et al. 2014). Quanto às contas feitas de conchas ${ }^{4}$ (discos cortados, perfurados e polidos), segundo Rafael A. Gassón (2000) estariam relacionadas com bens de prestígio e de trocas de longa distância e até mesmo "moedas".

No sítio arqueológico EVA II, também na Guiana Francesa, a ocupação do período pós-contato europeu (datada do século XVII ao XIX AD), foram registrados através dos negativos dos corpos a posição e orientação em que foram depositados. Esses foram colocados em fossas rasas, em deposição primária com os corpos fletidos, com exceção de um indivíduo com o corpo estendido (Bel 2006).

Em uma única deposição secundária foram identificados feixes de ossos em uma urna funerária, colocada verticalmente em uma grande fossa e tampada com outra vasilha grande emborcada (Bel 2015:519). Para cada sepultamento havia um indivíduo adulto, com exceção de uma provável criança em deposição primária fletida (Bel 2015:520-523).

Em seis dos oito sepultamentos foram encontradas contas de vidro, incluindo o sepultamento primário estendido e o secundário em urna, e, em pelo menos um destes, contas de vidro e contas de conchas faziam parte da deposição (Bel 2015:531). É interessante notar que o único sepultamento com conta de possível concha, é justamente o sepultamento primário com corpo 
estendido, cujas peculiaridades dentro do sítio levaram Martjin Van den Bel (2015) a propor que este seria um indivíduo com status único e diferenciado na comunidade.

$\mathrm{Na}$ Ilha do Marajó, as escavações nos sítios ao longo rio Camutins e no teso M-17 realizadas por Denise Schaan (2004) permitiram encontrar um sítio doméstico e cerimonial, com área de habitação e cemitério (cujas datações variam de 730 a 960 AD) no mesmo teso, porém com duas áreas distintas provavelmente indicando uma separação no mesmo teso entre uma área doméstica e uma área cerimonial onde se encontravam os sepultamentos (Schaan 2004:234).

Neste sítio foram encontradas 24 urnas funerárias, onde se pode ver que os sepultamentos eram secundários e primários. Tratava-se de remanescentes esqueléticos de crianças e adultos, mulheres e homens. Para cada indivíduo havia uma urna (quando os ossos estavam presentes), tendo como acompanhamento lâminas de machado, tangas pintadas e contas (Schaan 2004: 233).

$\mathrm{Na}$ ilha de Caviana e Mexiana, que compõem o arquipélago do Marajó, foram identificados por Curt Nimuendaju (Nimuendaju 2004) e Betty Meggers e Clifford Evans (1957) cemitérios contendo urnas funerárias e com vasilhas emborcadas usadas como tampas e enterradas ou parcialmente enterradas.

Em muitas dessas urnas foram identificados restos de esqueletos humanos, em sua maior parte descritos como indivíduos adultos, contendo contas, pingentes e adornos de rochas escul- pidas não identificadas, rochas verdes, muiraquitãs, contas de dentes (aparentemente de animais e também humanos), contas de vidro europeu e implementos de ferro que por sua vez as situam cronologicamente a partir do período do contato europeu (Nimuendaju 2004; Meggers \& Evans 1957).

Para o Estado do Amapá, junto à costa Atlântica, Nimuendaju relatou conjuntos de urnas funerárias Aristé situadas no Monte Mayé (Nimuendaju 2004:21). Neste local foram identificados três sítios de urnas funerárias com deposições secundárias, cujos ossos pareciam ter sido intencionalmente quebrados.

Colocados dentro ou ao lado das urnas pintadas e com apliques e tampadas com vasilhas emborcadas, foram identificados dedais de costura, pingentes, muiraquitãs, contas de conchas, contas de cerâmica, contas de vidro, facas de metal, contas de dentes, tembetás, fragmentos de ferro, espelhos, entre outros objetos. Devido aos acompanhamentos, se cogitou que se tratasse de um cemitério do século XVIII AD (Nimuendaju 2004:21-23).

Em Vila Velha, distrito do município do Oiapoque, no sítio Vila Velha I, Eurico Fernandes em 1935 identificou uma urna Aristé contendo contas de vidro, ossos queimados, um machado de pedra, sete muiraquitãs e pendentes de jadeita (Hilbert 1957:9). Próximo a este sítio arqueológico, no sítio Villa Velha II as urnas estavam mais próximas ao rio e afastadas uma das outras, em cujo interior foram encontrados ossos de inumação secundária, contas 
de vidro e dois guizos de cobre (Hilbert 1957:14).

Mais ao sul do Amapá, próximo ao rio Vila Nova, em Mazagão, foram identificadas urnas funerárias Mazagão contendo contas de vidro europeu (Meggers \& Evan 1957). Porém, o caso mais emblemático são as grutas e abrigos funerários na região do Maracá, cujas urnas funerárias antropomorfas continham esqueletos humanos encerrados em seus interiores, acompanhados por contas de vidro europeu (Lima Guedes 1897; Guapindaia 2001, 2008; Souza et al. 2001).

$\mathrm{Na}$ ausência de acompanhamento interno, uma construção corporal pode ser vislumbrada nas urnas Maracá onde diferenças sutis em relação a características anatômicas, sugerem características individuais, sendo as áreas de inserção dos ornamentos corporais (Barreto 2008; Barbosa 2011).

Em Macapá têm-se o registro de adornos como pingentes esculpidos em rochas em urnas funerárias, contendo ossos humanos misturados a sedimento, além de contas de conchas perfuradas que foram encontradas no interior de urnas em sítios cemitérios (Machado 1997; Meggers \& Evans 1957).

Esses exemplos citados, na realidade apenas uma parcela representativa deles, atestam a ocorrência desses objetos em contextos funerários, dos quais chamamos a atenção os adornos corporais presentes nas urnas, sejam dentro das urnas acompanhando os esqueletos nelas encerrados, ou em urnas antropomorfas com apliques cerâmicos representando ornamentos corporais.

Ao lidar com o contexto funerário presente no sítio Curiaú Mirim I, exposto logo abaixo, pode-se pensar como os corpos dos mortos podem romper ou estender as relações sociais. Do mesmo modo que a agência dos objetos pode ser visto como uma maneira de criar laços sociais mais duráveis, os corpos esqueletizados ou parte deles podem ter também essa capacidade. A análise de restos esqueléticos misturados e fragmentados, frequentemente, revela emaranhados entre pessoas e coisas, e entre os mortos e os vivos (Osteoholtz 2015:249).

\section{- ESTUdo de CASO dO SítIO CURIAÚ MIRIM I}

O sítio arqueológico Curiaú Mirim I (Saldanha \& Cabral 2012; Gambim Júnior, 2016; Saldanha 2017) está localizado na borda de um terraço junto a uma área de transição da floresta de várzea para o cerrado e encontra-se na bacia hidrográfica do Curiaú (Torres e Oliveira 2003) onde hoje é o município de Macapá, no Estado do Amapá, no norte do Brasil, situado na Amazonia Oriental, junto ao escudo das Guianas na foz do rio Amazonas, conforme pode ser vislumbrado no mapa abaixo (Figura 1). 


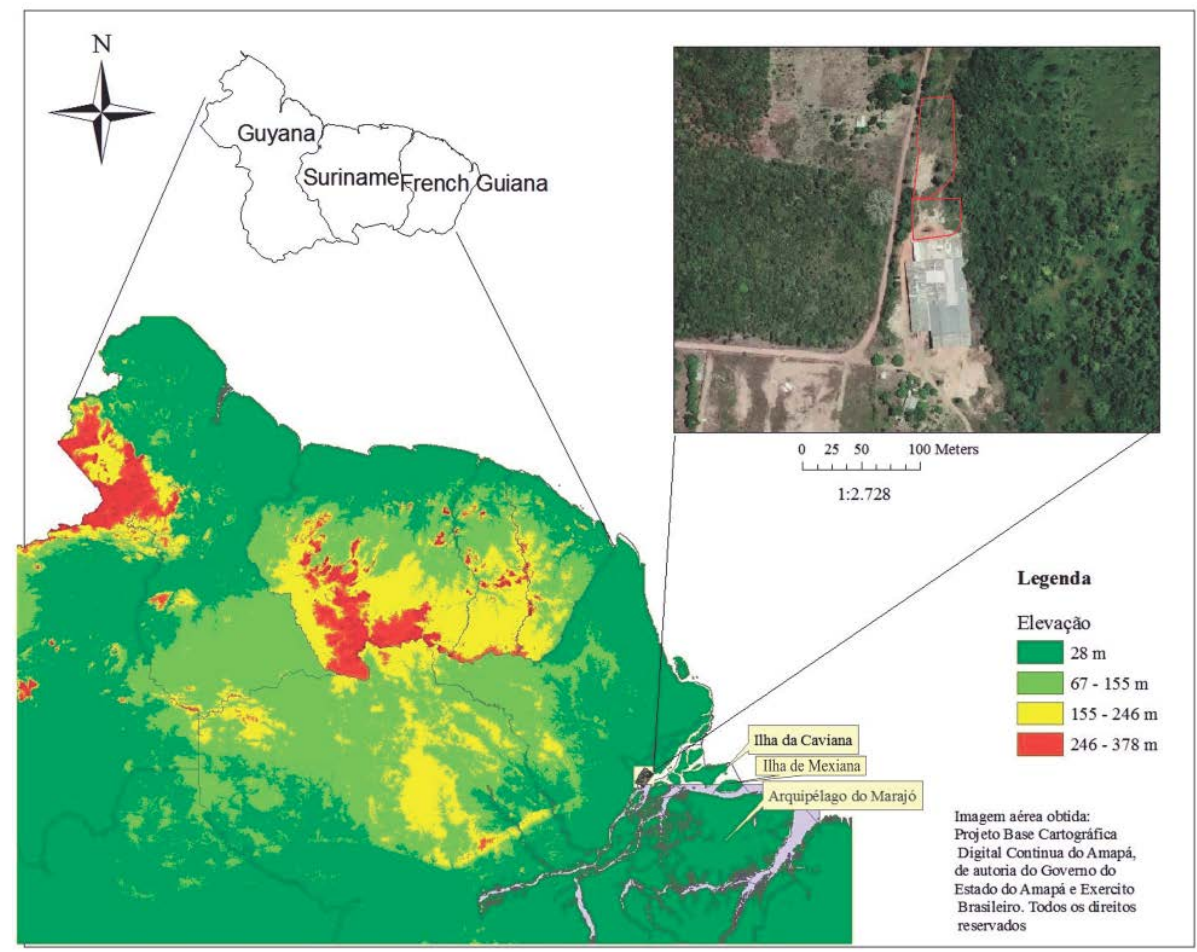

Figura 1 - Localização da cidade de Macapá e do Sítio Curiaú Mirim I (Mapa elaborado por Kleber Oliveira Souza com alterações de Avelino Gambim Júnior) Fonte: Gambim Júnior 2016.

Devido à terra preta e algumas das estruturas negativas tais como lixeiras e buracos de poste, o sítio tem sido interpretado como um sítio habitação com estruturas domésticas, indicativo de uma antiga aldeia indígena, onde foram igualmente evidenciadas áreas de deposições funerárias / cerimoniais (Saldanha \& Cabral 2012; Gambim Júnior 2016; Saldanha 2017) em uma área aberta totalizando $1070 \mathrm{~m} 2$ conforme pode ser observado no mapa abaixo (Figura 2).

Porém este sítio pode se tratar de um palimpsesto de ocupações, de modo que fica difícil ainda dizer, com base em apenas cinco datações absolutas, Júnior 2016) ou não. a contemporaneidade de uma possível aldeia que em algum momento teria sido utilizada como cemitério ou vice-versa, concomitantemente ou não. Desse modo não se descarta uma possibilidade de que este pudesse ser um sítio cerimonial, cujos buracos de poste não necessariamente indiquem antigas unidades domésticas, mas talvez algumas estruturas de caráter mais cerimonial. No entanto os resultados obtidos até o momento levam ao entendimento que neste sítio seriam feitos ritos de passagem, entre eles a passagem da morte e a celebração e culto aos ancestrais seja junto de uma aldeia (Gambim 
Foram identificadas diversas estruturas negativas como fossas, poços e deposições de vasilhas, buracos de poste (inclusive dentro de algumas dessas estruturas) e anomalias não escavadas que

possivelmente se tratem de negativos de esteios. No interior de pelo menos uma dessas fossas e dois desses poços foram identificadas estruturas claramente funerárias (Figura 2).

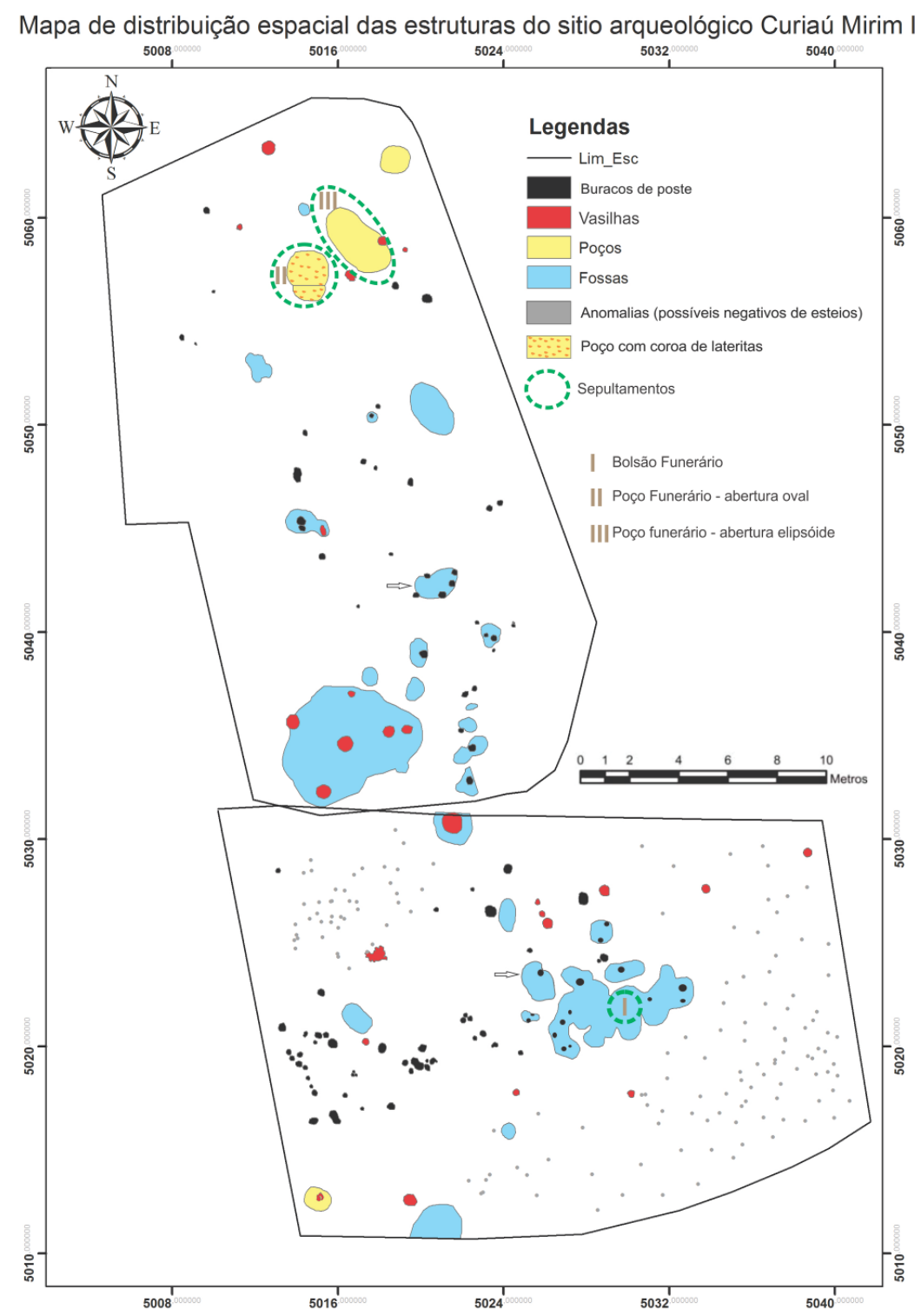

Figura 2 - Elaborado por João Darcy de Moura Saldanha e alterado por Avelino Gambim Júnior: as duas setas indicam estruturas cerimoniais (não funerárias) citadas no texto (Fonte: Acervo NuPArq/IEPA; Gambim Júnior 2016; Saldanha 2017). 
Além de claras evidências de sepultamentos conforme especificado no mapa acima, temos outros tipos de estruturas que podemos chamar de possíveis estruturas cerimoniais, algumas com vasilhas inteiras ou mesmo fragmentos de vasilhas cerâmicas decoradas cujos gestos de deposição dos conteúdos encontrados em fossas e poços parecem regidas por regras culturais (Lima et al. 2014; Gambim Júnior 2016).

Por sua vez, tais regras culturas estariam por trás de práticas culturais, entre elas os gestos de deposição (Thomas 1999), que podem se tornar perceptíveis através de "ações repetitivas formalizadas que podem ser detectadas arqueologicamente através de um modo altamente estruturado de deposição" (Thomas 2012), levando-nos a pensar nos espaços deste sítio como sendo caracterizados pelas formas específicas de deposição dos conteúdos nessas estruturas4, sejam elas especificamente cerimoniais/funerárias, sejam elas relacionadas aos depósitos de outra natureza (Gambim Júnior 2016).

Foram identificados no sítio quatro estilos cerâmicos, denominados Mazagão, Marajoara, Koriabo e Caviana que fazem parte desse universo cultural (Saldanha \& Cabral 2012). O que nos chama a atenção é o fato desses diferentes estilos cerâmicos como a cerâmica Koriabo que têm ocorrência além das Guianas e também as cerâmicas Caviana e Marajoara das Ilhas do Pará junto à foz do rio Amazonas, estarem juntas no sítio arqueológico Curiaú Mirim I justamente em estruturas de caráter aparentemente cerimonial (Saldanha \& Cabral 2012; Saldanha et al. 2016; Gambim Júnior 2016).

Em relação à cerâmica Koriabo, é interessante ressaltar que aparece justamente nessas estruturas cerimoniais junto de deposições de vasilhas, já em relação a cerâmica Marajoara esta poderia talvez estar relacionada a consumos rituais de alimentos relacionados aos sepultamentos (Gambim Júnior 2016; Saldanha et al. 2016) já que é comum estarem associadas a restos faunísticos e carvões.

Do mesmo modo, no espaço do sítio, parecem ter ocorrido, em outros setores, gestos repetidos e conteúdos muito similares, o que nos faz lembrar que devemos prestar atenção nos conteúdos e gestos de deposição nessas estruturas negativas, o que quer dizer que não devemos privilegiar a morfologia em detrimento dessas características e sim observarmos este conjunto de informações devidamente contextualizadas (Lima et al. 2014).

Cronologicamente o sítio Curiaú Mirim I está situado entre o século X AD até o século XVII AD (Gambim Júnior 2016; Saldanha 2017), segundo as datações radiocarbonicas obtidas para cinco estruturas negativas, classificadas como deposições funerárias e duas destas provavelmente de carater cerimonial, conforme descrito sumariamente na tabela abaixo (Tabela 1$)^{5}$. 


\begin{tabular}{|c|c|c|}
\hline Estrutura & $\begin{array}{l}\text { Idade Convencional (fonte/ } \\
\text { número do laboratório) }\end{array}$ & $\begin{array}{l}\text { Idade Calibrada } \\
\qquad-2 \text { sigma }\end{array}$ \\
\hline $\begin{array}{l}\text { Fossa com arranjo fu- } \\
\text { nerário /Bolsão fune- } \\
\text { rário }\end{array}$ & $\begin{array}{c}1020 \pm 39 B P \\
\text { (Saldanha 2017) }\end{array}$ & 948AD - 1051AD (77.8\%) \\
\hline $\begin{array}{l}\text { Bolsão cerimonial (com } \\
\text { restos de consumo ri- } \\
\text { tual) }\end{array}$ & $\begin{array}{c}720 \pm 30 B P \\
\text { (Saldanha 2017) }\end{array}$ & $1246 \mathrm{AD}-1302 \mathrm{AD}(90.5 \%)$ \\
\hline $\begin{array}{l}\text { Poço funerário com } \\
\text { câmara lateral (abertura } \\
\text { oval) }\end{array}$ & $\begin{array}{c}\text { 660 } \pm 30 \mathrm{BP} \\
(\text { Beta }-433345) \\
(\text { Gambim Júrior 2016) }\end{array}$ & $\begin{array}{l}1277 \mathrm{AD}-1323 \mathrm{AD}(47.6 \%) \\
1347 \mathrm{AD}-1393 \mathrm{AD}(47.8 \%)\end{array}$ \\
\hline $\begin{array}{l}\text { Poço funerário com } \\
\text { câmara tripla (abertura } \\
\text { elipsoide) }\end{array}$ & $\begin{array}{c}\text { 630 } \pm 30 \mathrm{BP} \\
(\text { Beta }-433346) \\
(\text { Gambim Júrior 2016) }\end{array}$ & 1287AD (95.4\%) 1399AD \\
\hline Fossa (cerimonial) & $\begin{array}{c}360 \pm 30 \mathrm{BP} \\
(\text { Beta }-433347) \\
(\text { Gambim Júrior 2016) }\end{array}$ & $\begin{array}{l}1450 \mathrm{AD}-1640 \mathrm{AD}(47.7 \%) \\
1540 \mathrm{AD}-1635 \mathrm{AD}(47.7 \%)\end{array}$ \\
\hline
\end{tabular}

Tabela 1 - Datações absolutas obtidas para o sítio Curiaú Mirim I (Fonte: Gambim Júnior 2016).

As estruturas arqueológicas que continham remanescentes esqueléticos são três ao todo: uma fossa com um arranjo funerário em seu interior (um bolsão funerário) e dois poços funerários com câmaras laterais (um com abertura oval e outro com abertura elipsoide e câmara tripla) todos em deposições secundárias, dos quais têm-se um número mínimo de 16 indivíduos, representado por indivíduos do sexo (biológico) femininos e masculinos e com idades variadas, e com idades (biológicas) desde bebês, crianças, adolescentes e adultos (Gambim Júnior 2016).

Além dessas estruturas que estão plotadas no mapa acima, está incluso aqui neste artigo uma quadrícula/ poço teste fruto de um resgate emergencial (não aparece no mapa6) cuja morfologia da estrutura não está clara, mas tudo indica que deva se tratar de uma fossa com um sepultamento secundário de um indivíduo adulto (Gambim Júnior 2016).

A fossa com arranjo funerário (Figura 3) possui formato irregular com vista superior com diâmetro máximo de 7,5 metros, e profundidade máxima de 90 $\mathrm{cm}$. Tal fossa é formada por um conjunto de três fossas, cuja fossa central é onde foi encontrado o arranjo funerário. Duas das fossas continham restos faunísticos e carvões que parecem estar relacionadas a um único contexto de deposição, sendo interpretadas como prováveis deposições relacionadas ao consumo cerimonial de alimentos provavelmente ligada a um evento cerimonial funerário.

O arranjo funerário ou bolsão funerário (séc. X a XI AD) em sí é formado por três sepultamentos secundários em 
urnas, uma vasilha votiva e três sepultamentos secundários depositados diretamente no solo (é possível que originalmente estivessem em invólucros
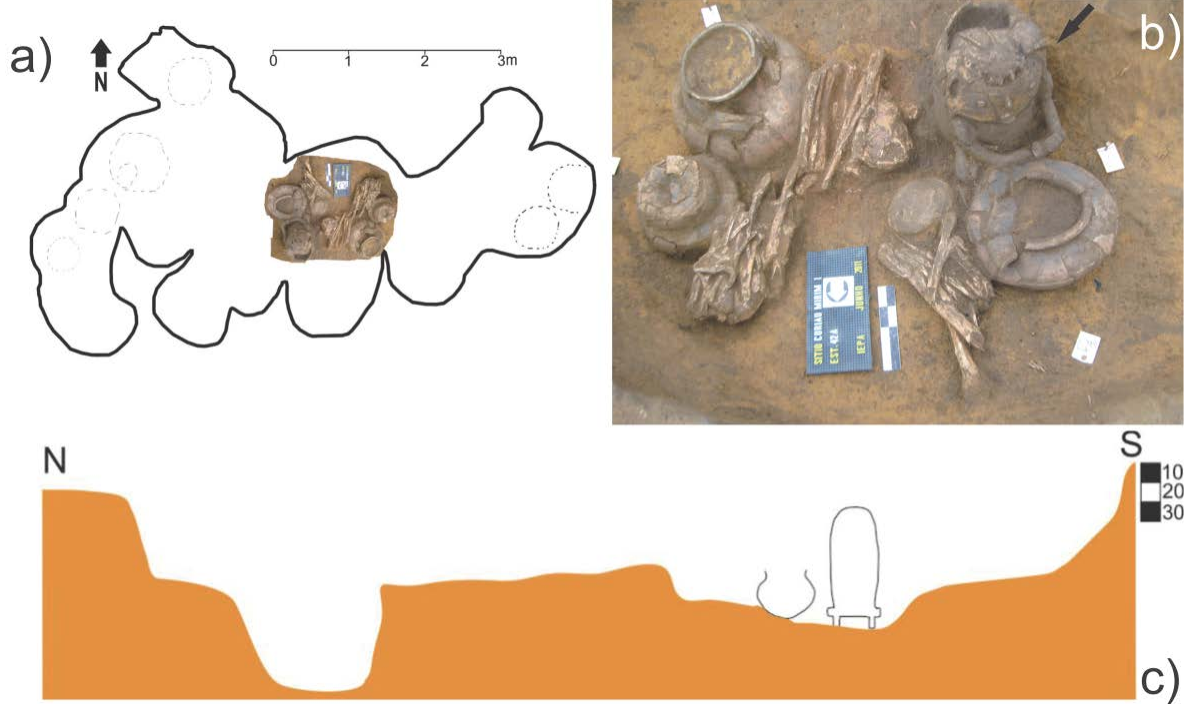

vegetais como esteiras, redes ou cestaria), sendo o elemento central com mais destaque uma urna antropomorfa Caviana.

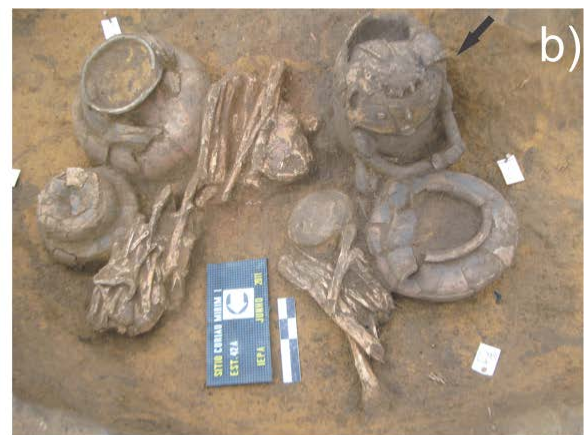

c)

Figura 3 - a) Desenho de topo da fossa com o arranjo funerário ao centro (fonte: Gambim Júnior 2016); b) Detalhe do bolsão onde encontrou-se o arranjo funerário, com uma seta indicando a urna antropomorfa Caviana (fonte: Saldanha \& Cabral 2012); c) Desenho do perfil norte-sul da fossa com detalhe do bolsão funerário à direita (fonte: Saldanha \& Cabral 2012; Composição da imagem: Jelly Juliane Souza de Lima).

É importante ressaltar, apesar de não fazer parte das estruturas aqui descritas, que muito próximo a este arranjo funerário (bolsão funerário) foi identificado um bolsão cerimonial (séc. XIII a XIV AD) com deposição de restos alimentares de um consumo cerimonial cuja datação bate com aquelas obtidas para os poços funerários (ver a tabela 1 referente às datações e o figura 2 , referente à dispersão das estruturas).

Quanto à morfologia do poço funerário com abertura oval (séc. XIII a XIV $\mathrm{AD})$, esta possuía um metro e oitenta $\mathrm{cm}$ de diâmetro máximo (Figura 4). Esta estrutura estava preenchida com terra preta e cacos cerâmicos. Na superfície, perceberam-se concentrações de blocos de laterita ou uma coroa de lateritas, que pareciam circundar acima do poço, possivelmente uma espécie de marcador. A profundidade dessa estrutura chegou a $1,95 \mathrm{~cm}$, terminada em uma câmera lateral com degraus delineados escavados no latossolo.

Não foi encontrada nenhuma evidência de reabertura e/ou remeximento do interior da estrutura, indicando ser um evento único de deposição. $\mathrm{O}$ interior da câmara lateral continha uma urna funerária lisa com tampa acompanhada de três potes e uma tigela. 

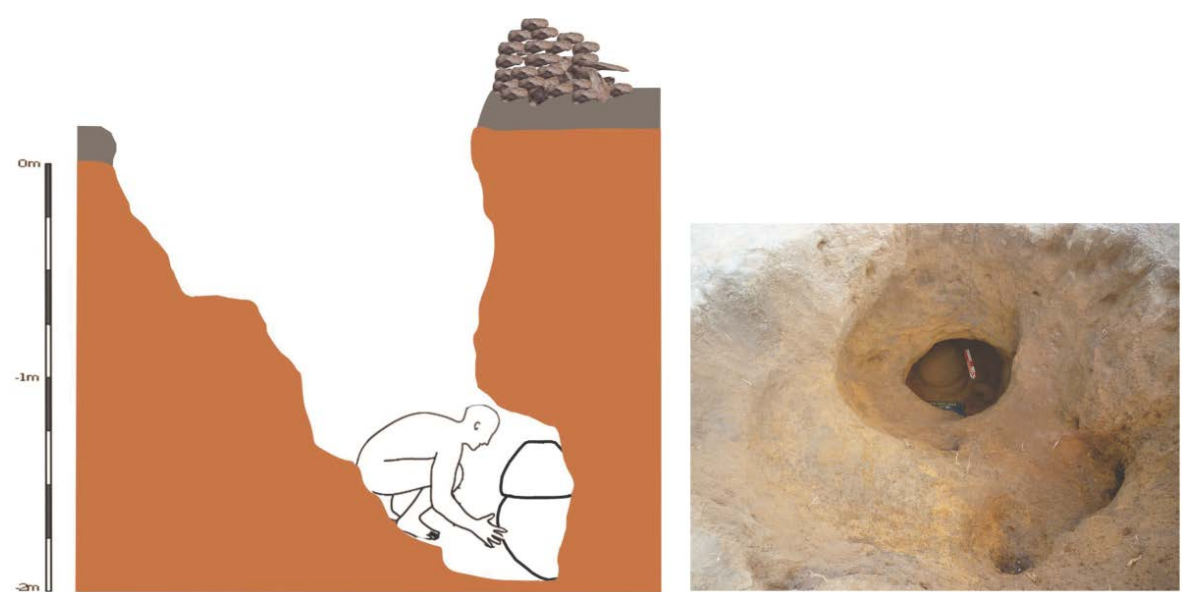

a)

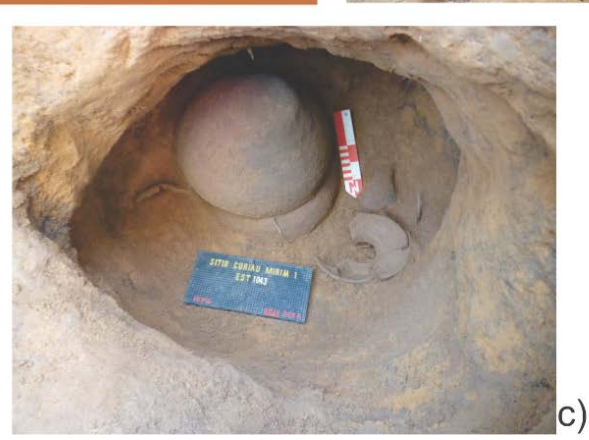

b)

Figura 4 - a) Desenho de perfil do poço funerário com a câmara lateral (fonte: Gambim Júnior 2016); b) Fotografia de topo do poço funerário (fonte: Acervo IEPA); c) Fotografia da câmara lateral com detalhe para a urna e seus acompanhamentos externos (Fonte: Acervo IEPA).

No poço funerário com abertura de formato elipsoide (séc. XIII a XIV AD) possui dois metros de profundidade máxima e três metros e oitenta centímetros de diâmetro máximo (Figura 5), preenchida por terra preta. Dentro da estrutura, foram encontradas três câmaras funerárias, escavadas no solo laterítico, dispostas de forma escalonada, isto é, uma mais baixa que a outra.
Todas as câmaras continham urnas funerárias com artefatos cerâmicos depositados ao seu lado, cada arranjo, cuidadosamente, colocado junto à parede de cada câmara funerária. Em duas das câmaras foram identificados ainda bancos cerâmicos depositados ao lado das urnas, uma de formato quadrangular e outra de formato circular, esta última localizada na câmara mais baixa (à direita na imagem abaixo), alvo da análise para este artigo. 

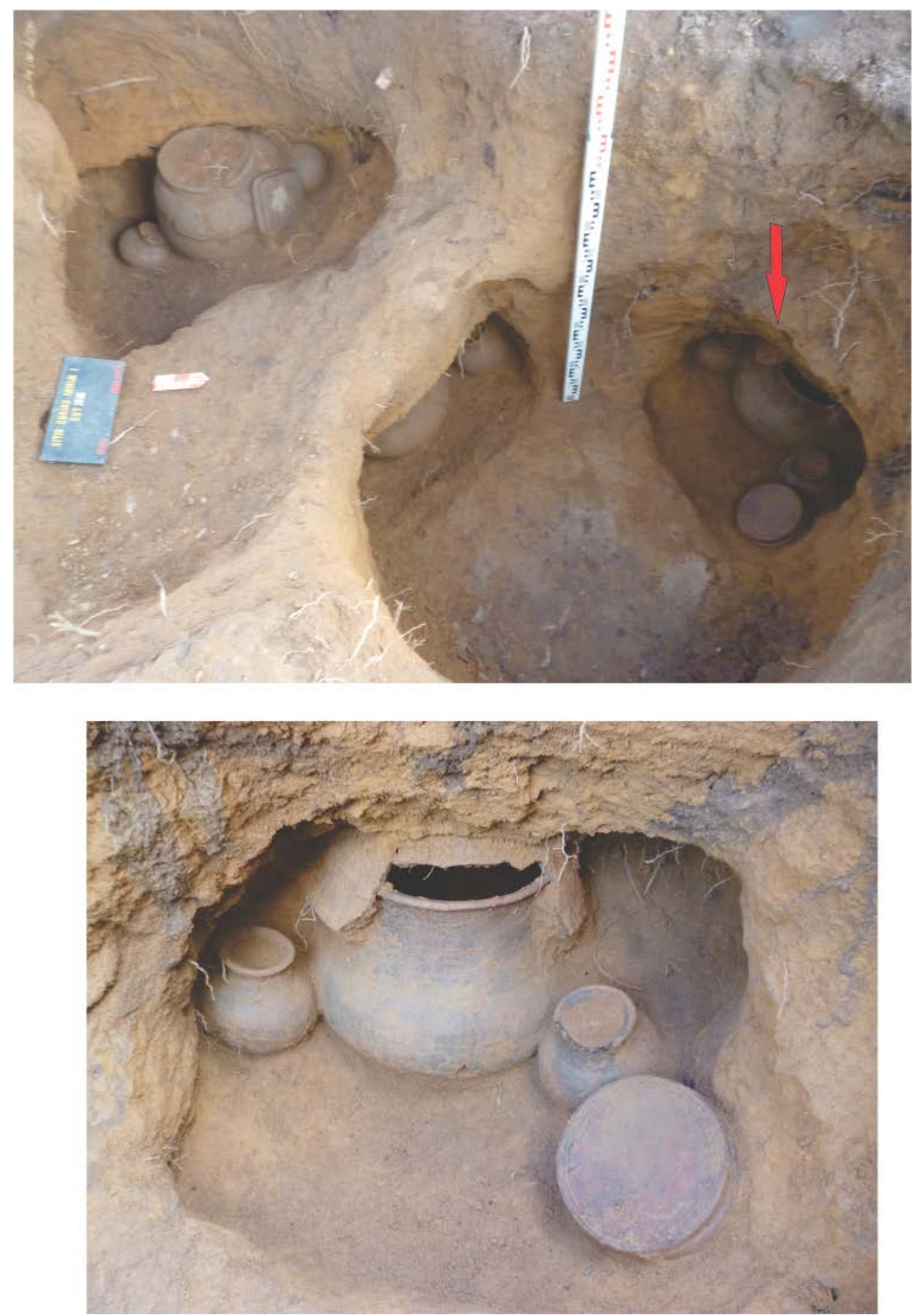

Figura 5 - Acima: Poço funerário com câmara tripla e seta apontando a câmara lateral mencionada neste artigo. Abaixo: Detalhe da mesma câmara funerária com a urna e seus acompanhamentos externos. (Fonte: Acervo IEPA).

É importante ressaltar entre esses dos uma lixeira. Porém foram encontradois poços funerários e o bolsão fu- dos buracos de poste em seu interior nerário foi identificada e datada uma de modo semelhante a outras estrutupossível fossa cerimonial (vide tabela 1 ras deste sítio, onde foram identificae figura 2), que a principio parecia ser dos fragmentos cerâmicos decorados 
(Marajoara e Koriabo), além de restos de fauna e carvões (Gambim Júnior 2016), porém sua datação é mais tardia (séc. XV ao XVII AD).

Sobre os acompanhamentos funerários a tabela abaixo (Tabela 2) sumariza as informações do que se identificou em cada estrutura funerária analisada, onde os adornos identificados dizem respeito não apenas aos objetos interpretados como ornamentos corporais dentro de urnas, como também se referem a urna antropomorfa com apliques representando adornos.

\begin{tabular}{|c|c|c|c|c|}
\hline Conteúdo externo e interno & $\begin{array}{c}\text { Poço com } \\
\text { camara lateral }\end{array}$ & $\begin{array}{c}\text { Poço com } \\
\text { camara tripla }\end{array}$ & Fossa & Poço teste \\
\hline Pote/vasilha (acompanhamento) & $\mathrm{X}$ & $\mathrm{X}$ & $\mathrm{X}$ & - \\
\hline Urna funerária globular lisa & $\mathrm{X}$ & $\mathrm{X}$ & $\mathrm{X}$ & $\mathrm{X}$ \\
\hline Tigela (acompanhamento) & $\mathrm{X}$ & $\mathrm{X}$ & $\mathrm{X}$ & - \\
\hline Banco cerâmico & - & $\mathrm{X}$ & $\mathrm{X}$ & - \\
\hline Urna funerária antropomorfa & - & - & $\mathrm{X}$ & - \\
\hline Restos esqueléticos humanos & $\mathrm{X}$ & $\mathrm{X}$ & $\mathrm{X}$ & $\mathrm{X}$ \\
\hline Restos de fauna & $\mathrm{X}$ & $\mathrm{X}$ & $\mathrm{X}$ & - \\
\hline Adornos & $\mathrm{X}$ & $\mathrm{X}$ & $\mathrm{X}$ & $\mathrm{X}$ \\
\hline
\end{tabular}

Tabela 2 - Vestígios identificados nas estruturas arqueológicas funerárias do sítio Curiaú Mirim I. A indicação do X refere-se à presença dos tipos de artefatos registrados.

\section{FOSSA COM ARRANJO FUNERÁ- RIO (BOLSÃO FUNERÁRIO)}

Em relação à urna antropomorfa denominada de Caviana (Figura 6), o corpo possui uma morfologia cilíndrica sendo assentado sobre um banco retangular. Quanto aos adornos, podem-se identificar apliques modelados de cerâmica iguais a braceletes, que possuem perfurações para encaixar possíveis penas. Nas pernas, existem tornozeleiras com perfurações que indicariam o possível encaixe de plumas.

Quanto à presença de pintura, o corpo da urna antropomorfa possui banho monocrômico branco na parte externa, localizados nos braceletes nos membros superiores e nas tornoseleiras dos membros inferiores da urna e na área da cabeça um banho monocrômico amarelo pode ser identificado.

A face antropomorfa possui sobrancelhas, dois olhos com formato de grãos de café, nariz, boca, queixo pronunciado e duas orelhas com perfurações nos lóbulos, como se tivessem brincos. No topo da cabeça uma espécie de coroa ou diadema (lembrando também uma representação de cabelos) compõe a ornamentação da urna antropomorfa. Outra informação identificada refere-se ao sexo da urna, com um aplique cerâmico no formato de um pênis. 


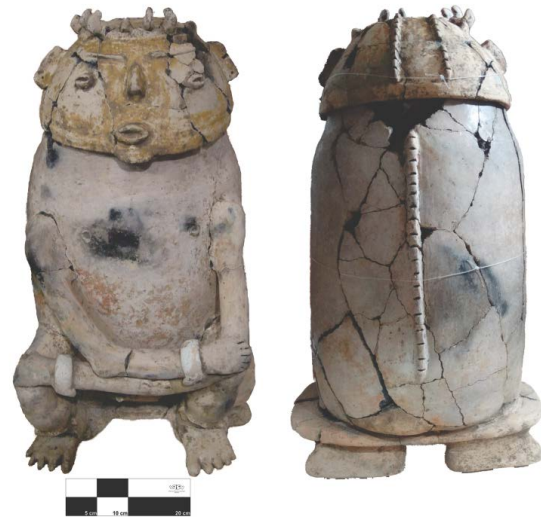

Figura 6 - Urna funerária Caviana (Fonte: Acervo NuPArq/IEPA). Autoria da foto esquerda: Alan Nazaré; autoria da foto à direita: Jelly Lima.

Com relação ao corpo, algumas projeções ou saliências junto às costas (às vezes descritas como possíveis vértebras) começam em dois ramos, dois menores que ficam na cabeça, se projetando da parte traseira do diadema e saindo do meio destes, outro ramo. Esse último continua como um único até chegar à altura da cintura, reforçando ainda mais a ideia de adornos e do corpo altamente decorado, podendo se tratar de uma espécie de cordão da parte traseira do diadema, como é muito comum em alguns povos indígenas na Amazônia. Entre os Palikur e os Karipuna do Oiapoque, por exemplo, esses adornos (Figura 5) são utilizados por homens e mulheres como:

“...coroas radiais (kubon, patoá; iyuli, palikur) [que] são delicados diademas feitos de penas de aves de várias cores, presas em uma armação de trançado ou algodão" (VIDAL, 2007) [do qual é preso ao] "butiê (ou mamã solei, patoá; maibá, palikur), um ornamento ritual de cordões de miçanga e borlas de algodão, usado nas costas amarrado ao butiê ou ao cabelo" (Vidal 2007).
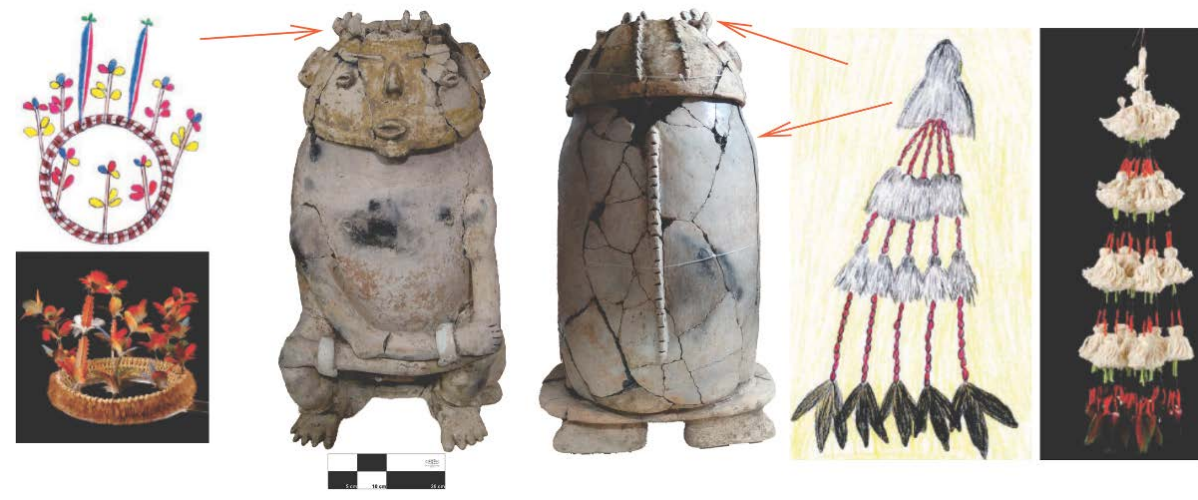

Figura 7 - À esquerda, exemplo de diadema na cabeça de urna antropomorfa Caviana. À direita, ornamento de cordões de miçanga e bolas de algodão preso no diadema ou aos Cabelos (Fonte: Pesquisadores indígenas do Museu Kuahí e Andrade, 2009) Composição da imagem: Jelly Lima. 
Sobre os remanescentes esqueléticos encontrados dentro da urna Caviana, os mesmos são de um indivíduo masculino com idade por volta de 16 a 24 anos, com ossos robustos e fortes marcações musculares. Os marcadores musculares conhecidos como entesofitoses (Capasso et al. 1999) na ulna direita e esquerda mostram tipos de atividades ocupacionais possivelmente relacionadas ao lançamento de projéteis, carregamento de fardos pesados, além de possível uso de remos em canoagem por exemplo (Capasso et al. 1999; Rodrigues Carvalho 2004).

Outra prática cultural relacionada a esse indivíduo masculino é a pintura vermelha aplicada nos ossos já secos, e indícios de provável descarne passivo talvez em superfície sujeito às intempéries e com alterações térmicas em alguns ossos longos possivelmente devido à exposição ao fogo (Gambim Júnior 2016).

Tanto o corpo cerâmico, as histórias corporais contidas nos restos esqueléticos e os gestos funerários relacionados ao indivíduo da urna Caviana reforçam uma posição de destaque que o indiví- duo teve na morte, certamente alguém com um status diferenciado (Gambim Júnior 2016), também evidenciado por estar associado a um banco que segundo etnografias amazônicas poderiam ser prerrogativa de chefes, líderes, guerreiros ou xamãs (McEwan 2001).

\section{POÇO TESTE/QUADRÍCULA}

No poço teste, numa urna funerária lisa de formato globular que estaria inserida em uma fossa, foram identificados os restos esqueléticos humanos de um individuo adulto, com ossos robustos e desgaste oclusal moderado nos dentes molares.

Como acompanhamento funerário havia um fuso cilíndrico feito a partir da matéria-prima de uma rocha verde (Figura 6) ainda não identificada. Esse tipo de artefato geralmente tem seu uso indicado pela literatura como um adorno labial, do tipo tembetá. Além deste ornamento cilíndrico, um fragmento de dente perfurado na raiz poderia ter sido utilizado como adorno já que foi colocado junto ao indivíduo.

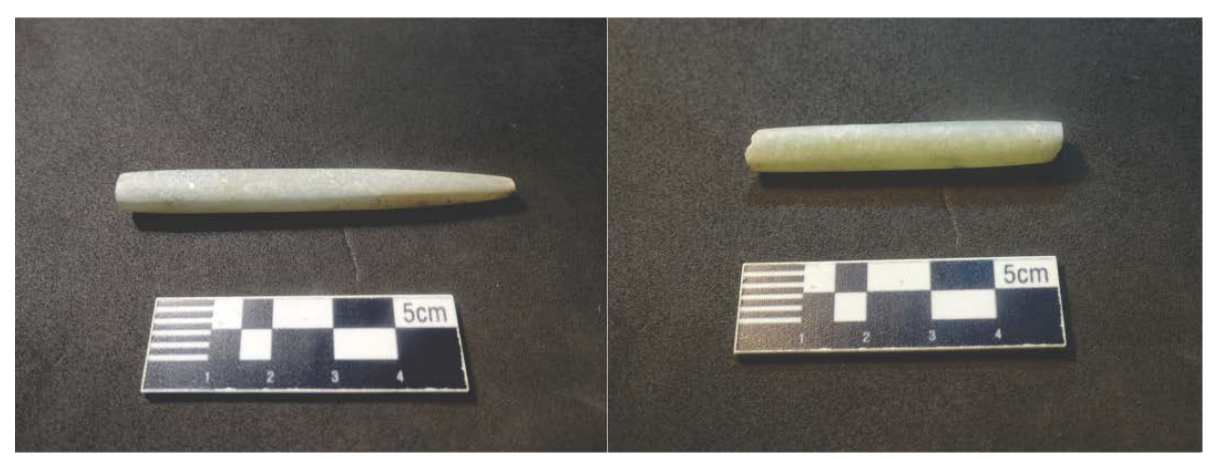

Figura 8 - Artefato cilíndrico manufaturado em pedra verde (Fonte: Acervo NuPArq/ IEPA; Gambim Júnior 2016). Autoria da foto: Avelino Gambim Júnior. 
POÇO FUNERÁRIO COM CÂMARA LATERAL (ABERTURA OVAL)

No poço (de abertura oval) com a parede reta e uma camara lateral, foram depositados na urna funerária ao menos quatro indivíduos, sendo um adulto possivelmente feminino com idade ente 20 a 35 anos, um infante de 1 a 2 anos de idade, um indivíduo perinatal com menos de 0 até no máximo 3 meses de idade, e uma criança ou adolescente entre 5 a 12 anos de idade (Gambim Júnior 2016).

Para os indivíduos adultos foram identificados marcadores musculares de atividades ocupacionais como três entesofitoses, em uma ulna direita, um calcâneo esquerdo e uma patela esquerda, todos demonstrativos de atividades intensas e repetitivas, possivelmente relacionados com longas caminhadas, possível uso de hastes longas para encostar o fundo de igapós e igarapés ao navegar em canoas, e/ou mesmo no uso de arpões ou zagaias no lançamento de projéteis (Capasso et al. 1999; Rodrigues Carvalho 2004; Abbas 2013).

Junto aos indivíduos contidos nas urnas, um achado inédito para a arqueologia e paleontologia brasileira pôde ser identificado (Gambim Júnior 2016; Gambim Júnior et al. 2017). Trata-se de colunais e pluricolunais de crinoides penduculares fosseis. Até o momento só há registro desses materiais em outros sítios arqueológicos pré-coloniais e históricos para a América do Norte e Europa por exemplo (Gambim Júnior 2016).

A partir dos relatos acima, levantou-se a hipótese de que os crinoides por ter sua forma discoidal e perfuração central que representa o canal do lúmen, foram utilizados como adornos (Figura 9) corporais (contas de colar ou pulseiras) em vida e/ou depositados junto aos mortos (Gambim Júnior 2016; Gambim Júnior et al. 2017). De aproximadamente 271 contas de crinoides, muitas estavam aderidas a calotas cranianas de indivíduos não adultos, mas isso parece ser devido a fatores pós-deposicionais.

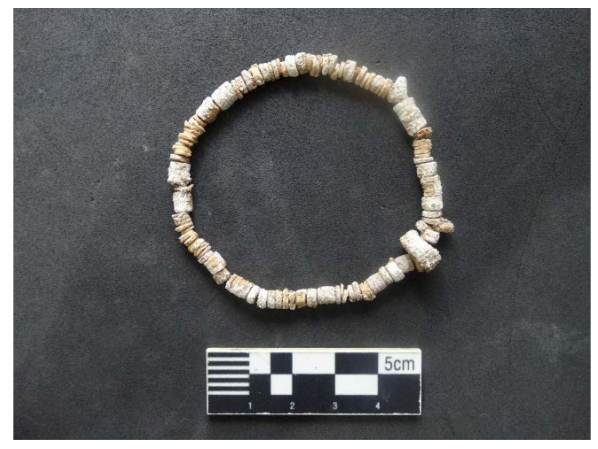

Figura 9 - sugestão de reconstrução de uma pulseira com Crinoides fósseis (Fonte: Acervo NuPArq/IEPA; Gambim Júnior 2016) Autoria da foto: Avelino Gambim Júnior

Outra hipótese aventada é a de que os colunais e pluricolunais de crinoides penduculares sejam provenientes da Formação Itaituba (Scheffler, informação pessoal 2015; Gambim Júnior 2016; Gambim Júnior et al. 2017), pois até o presente momento no Estado do Amapá depósitos com esse tipo de fóssil não foram mapeados.

Doze fragmentos de conchas cortadas em formatos variados desde quadrangular, retangular e triangular podem ser considerados como possíveis pré-formas de contas e pingentes. 
Dentro dessa urna funerária, três pingentes, dois deles perfurados, foram encontrados (Figura 10). O formato deles lembra um réptil, uma ave e um mamífero quadrúpede (da esquerda para a direita) conforme pode ser visto na imagem abaixo. Dada à adesão de um substrato carbonático (e a fragilidade da peça) não é possível identificar ainda a matéria-prima utilizada para confeccionar tais pingentes.

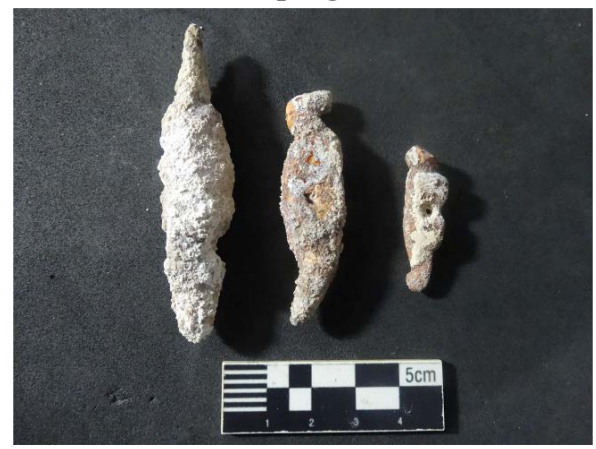

Figura 10- Pingentes zoomorfos envoltos em substrato carbonático (Fonte: Acervo NuPArq/IEPA; Gambim Júnior 2016). Autoria da foto: Avelino Gambim Júnior

\section{POÇO FUNERÁRIO COM CÂMARA TRIPLA (ABERTURA ELIPSOIDE)}

Em outra estrutura arqueológica classificada como poço com a parede irregular e três camaras laterais, na camara mais baixa identificou-se uma urna globular lisa com tampa, e acompanhamentos como um banco quadrangular cerâmico e dois potes pequenos. Dentro da urna, foi evidenciada uma deposição secundária com um número mínimo de dois indivíduos, um indiví- duo adulto com idade estimada entre 16 a 35 anos e um infante com idade entre 0 a 3 anos.

Os ossos do indivíduo mais velho são muito robustos e avantajados, com corticais espessos e com fortes inserções musculares, como por exemplo, osteofitose na tuberosidade do rádio direito, que talvez estivesse relacionada a atividades como carregamento de peso e uso de remos em canoagem (Capasso et al. 1999; Rodrigues Carvalho 2004; Abbas 2013).

Além disso, foi possível identificar em algumas vértebras lombares osteófitos que podem estar relacionadas também com o carregamento/levantamento de objetos pesados e/ou relacionado com a idade (Capasso et al. 1999; Mann \& Hunt 2013).

Os ossos do indivíduo adulto estão pintados de vermelho e não foram identificados fragmentos de crânio de indivíduo adulto na urna, estando presentes somente fragmentos de ossos de crânio de indivíduo infante.

Dentro da urna, junto aos ossos foram identificadas ainda quatro contas de dentes de felino de grande porte com perfurações na raiz, vinte e oito contas de dentes humanos com perfuração na raiz (Figura 11 à esquerda); vinte e sete contas de crinoides fósseis, duas contas de conchas (Figura 11 à direita) e um objeto avermelhado que parece se tratar de uma bolota de argila com hematita e possivelmente urucum. 

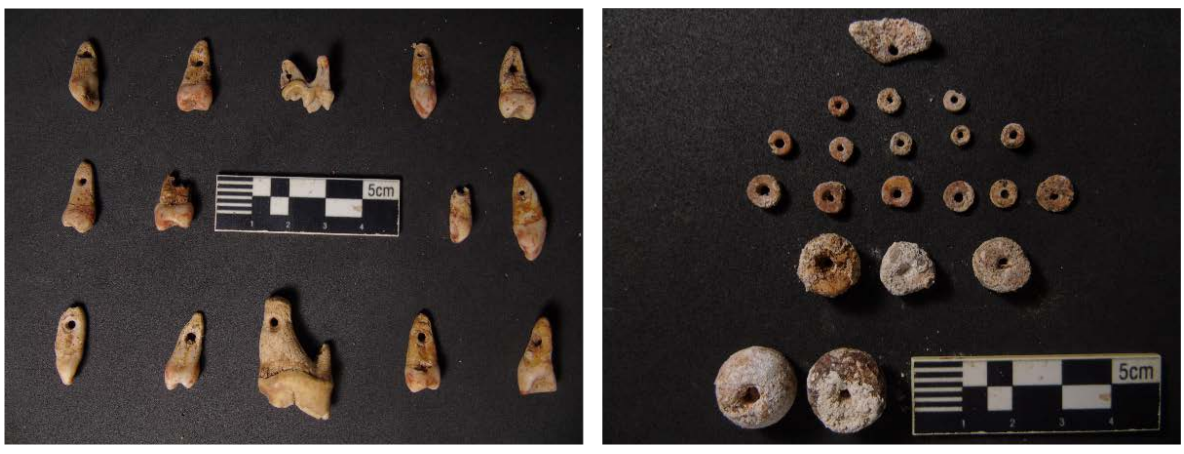

Figura 11 - À esquerda: Contas de dentes humanos e de felino de grande porte; À direita: Contas de concha,em rocha e crinóides fósseis (Fonte: Acervo NuPArq/IEPA; Gambim Júnior 2016). Autoria das fotos: Avelino Gambim Júnior

ADORNOS E A CONSTRUÇÃO DE PESSOAS: UMA HISTÓRIA DE LONGA DURAÇÃO

Conforme Lagrou (2012), contas transitam entre diferentes mundos, sendo muitas vezes um tema caro aos arqueólogos (Gassón 2000; Scaramelli \& Scaramelli 2005; Falci 2015). Trata-se de artefatos encontrados desde o mundo antigo em túmulos e testemunho das redes de intercambio entre as diferentes nações mesmo antes de Cristo (Lagrou 2012: 22). Se dentro de um contexto geral, esses artefatos estavam vinculados a uma relação comercial de longa distância, na arqueologia amazônica outras relações podem ser indicadas além destas.

Ornamentos feitos de pedras verdes e de outras rochas teriam tido uma ampla dispersão na Amazônia, incluindo as Guianas e indo até além, para as ilhas do Caribe, caráter muito mais evidente e estudado no caso dos muiraquitãs, dado seu caráter emblemático de objeto de prestigio. Tais contas e pingentes esculpidos em rochas têm sido encontrados principalmente asso- ciados com sepultamentos (Boomert 1987; Machado 1997; Costa et al. 2002; Coutet 2014; Falci \& Rodet 2016). Fazem parte desta categoria, os adornos com formato cilíndrico aqui apresentado que se assemelham a tembetás, associados a uma conta de dente perfurado na raiz.

O uso de objetos cilíndricos seja no lábio ou nos lobos da orelha são muito comuns em diversas sociedades indígenas do passado e do presente, e no caso de tembetás apesar de comuns ao tronco linguístico tupi ou guarani ou da tradição cerâmica Tupi-Guarani (Noelli 1996), são igualmente usados por outros grupos e dependendo do contexto e sociedade tanto por indivíduos do gênero masculino ou feminino, porém se tratando do individuo adulto de ossos robustos ao qual este artefato está associado, podemos propor ao menos que este seria um objeto de prestígio, dado a sua rara ocorrência nos contextos aqui apresentados.

Além da indicação dos ornamentos como emblemas de prestígio dentro de uma sociedade, surge a ideia de que 
contas de conchas poderiam ser utilizadas como Quirípa. O quirípa é conhecido desde o início do período colonial no oeste da Venezuela. As contas de concha ou quirípa eram pequenos discos perfurados feitos de conchas de várias espécies de água doce chamadas de nemu ou memu (Gassón 2000:548). Sabe-se que na bacia do Orinoco, a distribuição das contas de conchas utilizadas pelas pessoas estavam vinculas a redes de troca, que conectavam regiões como os Lhanos na Colômbia, Trinidade e as Guianas (Gassón 2000:548).

Muito já se cogitou sobre sua natureza e função, sendo sugerido inclusive que o quirípa servisse como moeda, fazendo parte de um tipo de sistema monetário, como por exemplo, colares de contas de conchas usadas como itens de troca, descritas também em relatos de cronistas entre os Galibi que se referiam aos mesmos como Okayes e entre os Arawak de Berbice na Guiana que os chamavam de orewebbe (Bel 2015:531).

Tais objetos faziam parte de uma ampla rede de trocas nas Guianas, eram desse modo itens muito estimados, porém muito menos pelo valor intrínseco, mas porque tais contas significavam muito mais o status de quem participava de uma ampla rede de trocas. No registro arqueológico da Guiana Francesa, anteriormente exposto, as contas discoides de conchas encontradas nos sítios arqueológicos como Eva 2 (Bel 2015) e Awala Yalimapo (Coutet et al. 2014) faziam parte do universo funerário igualmente ao sítio Curiaú Mirim I onde em duas urnas funerárias foram identificadas contas e pingentes de conchas.

Conforme pudemos observar as contas estão muito presentes não apenas no sítio aqui analisado, mas está amplamente disperso, especialmente em contextos funerários. Quanto a isso é importante lembrar que Franz Scaramelli e Kay Scaramelli (2005) propõem que as contas de vidro, ou miçangas são de fato um bom tipo de artefato para pensar no reforço das identidades e construção da pessoa e aquisição de valor dentro da longa duração de um sistema de uma ampla rede de trocas, que incluía diversos itens remontando ao passado da Antiga Amazonia e chegando até os dias atuais.

A circulação de bens e troca de presentes é um tema recorrente na etnografia ameríndia, além de bens de prestígios que podem atestar trocas de longas distâncias, durante os processos de circulação de ideias: cintos, colares, pingentes, estatuetas zoomorfas, potes (cerâmicas Marajoara e Koriabo por exemplo), etc.

Em se tratando dos ornamentos em alguns casos no sítio aqui estudado certamente estariam relacionados à exibição e construção dos corpos possuindo então um caráter positivo perante aos vivos como no caso do corpo altamente ornamentado representado pela urna Caviana demonstrando neste caso um culto aos ancestrais.

Mas ainda assim houve outros sepultamentos no sítio que talvez indiquem túmulos familiares e igualmente um culto aos mortos, onde o enterro de contas e pingentes junto aos mesmos como no 
caso dos poços funerários poderiam durante a construção de sociabilidades serem simbolizadas durante festins funerários e gestos mortuários nos quais seriam depositadas, podendo ter igualmente um aspecto de procurar livrar da circulação e da vista dos vivos objetos que poderiam possuir um peso negativo se permanecessem entre os vivos.

Neste quesito existe a meu ver uma semelhança persistente, que é a localização de sepultamentos em contextos aparentemente domésticos, que poderia ser uma evidência de túmulos ancestrais, sendo continuamente habitados e repetidamente usados como cemitérios (Gambim Júnior 2016) ao longo do tempo. O que reforçaria uma ideia de memória social, onde as pessoas reconstroem suas casas junto aos mesmos locais em que enterram seus mortos ao longo de vários séculos (Hoogland \& Hofman 2013:463).

A aproximação, entre o local de deposição das urnas e as casas, demonstraria a necessidade da proximidade com os mortos, que seria uma metáfora para proximidade cosmológica e talvez uma necessidade de legitimação social de uma linhagem (Schaan 2003). Tal ideia é reforçada pelas outras possíveis evidências de sepultamentos e depósitos cerimoniais (Gambim Júnior 2016).

Parte do processo relacionado aos adornos contempla práticas simbólicas. Mesmo sabendo das limitações de usar o presente etnográfico para inferir o passado arqueológico, como bem colocam Scaramelli \& Scaramelli (2005:157) talvez existam "algumas si- milaridades dentro da esfera do valor e produção social".

Nas etnografias recentes entre os WaiWai e Piaroa citadas por Scaramelli e Scaramelli (2005: 155-156) é mostrado que as contas de vidro são imbuídas de um valor extraordinário, incorporando os mais elevados valores sociais dentro de cada uma das sociedades apresentadas "incorporando localmente as potencias "estrangeiras" que corporificam. Seu valor reside na sua exibição que é determinada por e determina o status social do portador" (Scaramelli \& Scaramelli 2005:156)

O autor demonstra a atualidade que as noções de construção de corpo e noções de pessoa possuem em diversas sociedades ameríndias, onde as contas entre os WaiWai das Guianas e Piaroa do Orinoco, possuem, assim como os corpos humanos que os adornam, papéis de gênero e idade específicos para a reprodução social, funcionando como "sinais qualitativos" denotando nas palavras do autor " domínio de certos conhecimentos, controle social de sí mesmo e uma alma amadurecida e "endurecida" (Scaramelli \& Scaramelli 2005:156), como uma objetificação de corpos humanos específicos (Rival 2005).

Levando em consideração a profundidade histórica e temporal de redes de relações e trocas entre as Guianas (Gallois 2005) ao nos voltarmos a contas que possivelmente não são de produção local poderiam representar valores estéticos de apropriação de objetos externos aos contextos culturais que são inseridos, numa "bricolagem com 
unidades que carregam consigo os laços metonímicos das suas origens" (Lagrou 2012:44).

Quanto às contas de dentes humanos e de animais, estas teriam significados especiais para as sociedades amazônicas no passado. Segundo fontes etnohistóricas das Guianas o uso destes colares, braceletes e brincos manufaturados nestes materiais pareciam ter ampla difusão (Roth 1924). Segundo relato de Valter Roth (1924:432), o uso de colares de dentes humanos de inimigos vencidos em batalha era muito difundido entre os Caberre (Arawak) e grupos Caribe.

Valter Roth (1924:432-433) lembra que entre os Arawak era difundido o uso de grande quantidade colares com dentes de onças, jacarés e catitu que caçaram. Da mesma forma era importante para os indígenas do Suriname, que os penduravam sobre os ombros como troféus ou medalhas de caça, sendo também comum o uso de colares de outros dentes faunísticos entre as mulheres e crianças arawak, caribe, atorai wapixana e macuxi em alguns casos usados como espécies de talismãs, para proteção (Roth 1924:432-433).

Segundo Chaumeil (2005) os guerreiros Yagua da Amazônia Peruana faziam colares de dentes de inimigos que eram carregados como troféus, com caninos superiores e inferiores colocados junto ao peitoral e às costas, como se estivessem "capturados" pelas mandíbulas dos inimigos. Da mesma forma, segundo aponta Lagrou (2012) os dentes são o locus da força vital de acordo com muitas sociedades ameríndias.
Voltando aos indivíduos sepultados, neste caso a urna funerária do poço com câmara tripla, ao olharmos os ossos robustos e inclusive algumas possíveis atividades ocupacionais relacionadas assim ao indivíduo mencionado, podemos somar estas linhas de evidências aos ossos pintados de vermelho e a presença de dentes humanos e dentes de felino de grande porte.

Muito possivelmente, as contas de dentes humanos pertenceriam ao indivíduo adulto se levarmos também em consideração relatos etnográficos que apontam tal prática e uso destinado a guerreiros (Roth 1924; Chaumeil 2007), o que condiz com os ossos avantajados e marcadores de estresse ocupacional presentes nos ossos deste indivíduo.

Quanto aos dentes do felino esse poderia ter pertencido tanto ao indivíduo adulto quanto ao infante, ou como um troféu de caça no caso do adulto, por exemplo, ou como um amuleto de proteção no caso do infante, ambos os casos já observados etnograficamente (Roth, 1924). Talvez, pelo fato de termos dentes humanos junto a dentes de onça, ambos perfurados na raiz, e dada a pouca representatividade dos ossos infantis podemos nos inclinar a pensar que este seja um acompanhamento do indivíduo adulto (ver Gambim Júnior 2016 para mais detalhes relacionados a essa prática no Amapá e no sítio Curiaú Mirim I).

É igualmente importante ressaltar que tal indivíduo adulto não possui fragmentos do crânio representados no interior da urna, o que poderia segundo 
relatos históricos junto a sociedades ameríndias estar relacionado a práticas cerimoniais cujas diferentes partes do esqueleto do morto poderiam ser distribuídos entre parentes e ter destinos finais diferenciados (Chaumeil, 2007), como é o caso dos Siriono (tronco linguístico tupi-guarani) que enterravam somente o pós-crânio, sendo guardados somente o crânio (de parentes com status diferenciado) para fins cerimoniais e mágicos (Viveiros de Castro 1986; Chaumeil 2007), o que poderia reforçar anda mais a ideia das contas de dentes humanos e de felino terem pertencido ao indivíduo adulto.

Na região de Monte Alegre, área de ocorrência da cultura Santarém há afloramentos do carbonífero onde já se mapeou crinoides fósseis. Além disso, a urna antropomorfa Caviana, possui algumas características estilísticas que se assemelham a algumas figuras antropomorfas Tapajônicas, algo que poderia reforçar uma idéia de mobilidade e movimentações dentro de uma possível rede de trocas e relações ou ainda um ethos compartilhado entre essas regiões do baixo Amazonas e da foz do Amazonas.

Dentro da lógica da corporalidade na constituição da pessoa ameríndia, chamamos a atenção que essas contas de dentes, de conchas e de crinoides fósseis, os pingentes zoomorfos e (possíveis) adornos labiais podem fazer sentido dentro do que Terence Turner (2012) identificou como "pele social" na etnologia ameríndia, especificamente no Brasil Central, onde o corpo é um suporte para a representação social nas diferentes eta- pas e papéis socias que alguém passa durante seu ciclo de vida.

Entretanto, a abordagem proposta por Turner (2012) apesar de válida e até ser uma possibilidade em relação aos dados aqui expostos, representa uma visão do corpo um tanto restrita, ao enfatizar que a "pele social" é imposta sobre o corpo biológico, tornando-o social. Essa proposição foi revista com algumas ponderações por parte de outros antropólogos.

Como exemplo buscou-se destacar como os objetos estão imbuídos das percepções quanto à "composição do universo e dos seres que o povoam, sobretudo dos que estão alijados da sociedade: mortos, inimigos, animais e seres sobrenaturais" (Miller 2007:06).

Desse modo, na antropologia social, a partir da década de 1990 se observa uma valorização do universo dos artefatos e sua relação com a construção da pessoa, como pode ser visto em etnografias de Lúcia Van Velthen (2007) entre os Wayana, com Els Lagrou (2007) entre os Kashinawa, com Barcelos Neto (2008) entre os Wauja e no volume The occult life of things editado por Santos-Granero (2009) onde reúne diversas etnografias. Estes trabalhos têm em comum o interesse em mostrar a existência de outras relações entre as coisas e as pessoas, de acordo com as ontologias ameríndias.

Inspirados nisso, na arqueologia amazônica viu-se a tentativa de buscar outras formas de entender a inserção de artefatos nos contextos em que são revelados, levando a repensar questões como a agência dos objetos sobre as 
pessoas, a capacidade de objetos intermediarem ações sociais, além da eficácia ritual e simbólica de tais artefatos, bem como outras questões como a materialização de idéias e até mesmo o reconhecimento do estatuto ontológico desses, segundo o qual os objetos podem ser pessoas (Barreto 2008; Gomes 2007, 2010, 2012, 2016; Cabral 2014).

Todavia, quando falamos dessas inspirações, principalmente em relação aos estatutos ontológicos, como bem adverte Gomes (2012:140) objetos estáticos recuperados de seus contextos arqueológicos dificilmente terão seu estatuto ontológico reconhecível, mas podemos pelo menos em alguns casos discutir essas possíveis dimensões sociocosmológicas dentro do registro arqueológico quando devidamente contextualizados.

Como exemplo, a autora (Gomes 2010) descreve um bolsão ritual, este contendo somente vasos cerimoniais da cultura Santarém, intencionalmente quebrados. Essa prática de destruição foi associada à possível agência negativa desses artefatos poderosos, que foram removidos do contato com as pessoas uma vez que poderiam causar danos (Gomes 2016:6).

Ao contrário de realizar uma analogia direta, a autora (Gomes 2016) se valeu tanto de etnografias quanto relatos de cronistas quanto à história indígena na região amazônica, mas principalmente guiou-se através dos contextos onde tais objetos estavam inseridos, procurando romper de certa forma com uma divisão entre idéias e realidade, levando em consideração os diferentes mundos materiais e suas múltiplas ontologias (Thomas 2015).

A arqueologia pode nesse sentido ao utilizar o método etno-histórico "contribuir sobremaneira para que se possa pensar a história indígena a partir de um ponto de vista mais integral" (Cavalcante 2011:362) e abrangente promovendo a descolonização do discurso histórico onde os povos indígenas são tomados como sujeitos históricos plenos não ignorando os processos históricos que estiveram inseridos (Cavalcante 2011:366).

Desse modo, o uso das etnografias serve para expandir os horizontes da interpretação do arqueólogo, porque "a bem da verdade o uso cuidadoso dos dados etnográficos tem servido a uma causa importante que é a de apresentar as possibilidades das razões variadas e heterogêneas ou causas para a prática" (Ucko 1969:262), de modo a serem somados aos dados contextualizados através da arqueografia e do uso e escolha do corpo teórico e metodológico adotado.

Através da abordagem da bioarqueologia social (Sofaer 2006; Stodder \& Palkovich 2011) e tanatoarqueologia (Duday 2006) procurei empreender as relações entre os objetos e as pessoas, por perceber que ali, o corpo, era uma chave. Dentro desta perspectiva de enxergar os dados arqueológicos, "a osteoarqueologia e a arqueologia interpretativa têm o mesmo objetivo - explorar a contingência e instabilidade da materialidade do corpo através da noção da prática social" (Sofaer 2006:143). 
Ao inserir a osteobiografia daqueles indivíduos sepultados, expandimos "nosso foco em direção ao entendimento cultural dos eventos durante a vida, buscando integrar também a história dos restos humanos após a morte, por isso se faz útil os estudos tafonômicos” (Robb 2002:160), pois ao estudar os esqueletos e os sepultamentos, procuramos enxergar as modificações culturais no corpo durante a vida e após a morte e entender exatamente os vivos que os enterraram.

Como exercício de procurar imaginar os cenários de exibição, construção e transformação de corpos, o cerimonial funerário de caráter interétnico do Kuarup no Alto Xingu, devido à sua riqueza de detalhes permite pensar nas regras culturais relacionadas aos tratamentos dados aos corpos e a diferença observada em relação a chefes, líderes ou descendentes de chefes em relação às pessoas "comuns" (Junqueira \& Vitti 2009; Barcelos Neto 2012).

Tal como o Kuarup é possível que rituais de passagem, tais como acontecem neste evento ritual funerário, estivessem ocorrendo no sítio Curiaú Mirim I, como a iniciação de rapazes e moças, as reclusões e a posterior apresentação de um novo corpo diante da comunidade (Viveiros de Castro 1979, Miller 2007; Barcelos Neto 2012). De modo que onde fica evidente uma integração entre as coisas e as pessoas e sua relação com idéias de corporalidade ameríndia.

Outras interpretações que possibilitam inferências importantes se referem justamente a construção dessas sociabilidades e exibição dos corpos tanto dos vivos quanto dos mortos relacionados a distinções de famílias e clãs no tratamento funerário e colocação de objetos pessoais do morto junto ao poste do Kuarup, o duplo do morto, que neste caso, como já proposto por Barreto (2008) poderíamos substituir os mesmos por urnas funerárias arqueológicas. O que no caso do Curiaú Mirim I, parece ser o caso do bolsão funerário, que parece muito mais evidente principalmente com a urna Caviana ser algo como o duplo do morto.

É ainda descrito no kuarup o consumo de alimentos e bebidas, além da circulação de objetos e artefatos diversos, onde terminada a celebração "os fogos são apagados e as cinzas e carvões devem imperativamente ser enterrados, sob o risco de as almas ficarem vagando pela aldeia" (Barreto 2008:58). É possível que no sítio Curiaú Mirim I algo semelhante tenha gerado os bolsões e fossas cerimoniais já citados, ideia que ganha reforço se lembrarmos dos poços funerários e demais estruturas cerimoniais evidenciadas no sítio em questão.

Em relação aos mortos estes foram depositados em locais específicos e marcados no espaço dentro do sítio, como possíveis postes marcando os locais de sepultamento e possivelmente também estruturas cerimoniais com evidencias de consumos cerimoniais (Gambim Júnior 2016) de alimentos e bebidas (Figura 12), que também tem evidências de possíveis habitações ${ }^{7}$, evocando a importância da memória em relação aos mortos (Gambim Júnior 2016; Saldanha 2017). 


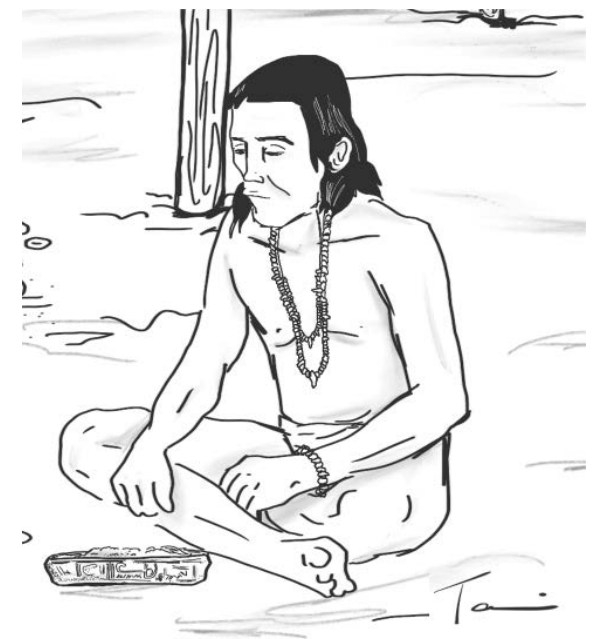

Figura 12 - As associações entre os contextos funerários e as demais evidências permite que possamos interpretar o próprio sítio, inferindo cenários onde emergem cosmologias, ideologias e identidades. Fonte: Gambim Junior 2016. Autoria do desenho: Tami Martins.

\section{CONSIDERAÇÕES FINAIS}

O que a análise dos dados arqueológicos provenientes do estudo de caso do sítio arqueológico Curiaú Mirim I parece demonstrar é que a noção de corporalidade construída, como possibilidade interpretativa, presente nos dias atuais entre diversas sociedades indígenas, pode ser inferida no registro arqueológico. Através das tentativas de reconstruções das identidades presentes nos restos esqueléticos humanos que os ornamentos puderam fazer sentido e dar sentido aos mesmos e também àqueles que os sepultaram.

Percebemos a ocorrência de contas e outros ornamentos em contextos essencialmente funerários sugerem que a ideia da exibição e construção dos corpos humanos não humanos possui ampla profundidade temporal de menos 1000 anos chegando aos dias de hoje.

Quanto ao que pode ser uma demonstração de possíveis rupturas e mudanças culturais ou mesmo variabilidade cultural, percebemos uma inconsistência ao comparar os relatos de cronistas e etnografias do século XVIII AD em diante referentes a práticas funerárias e sua relação com a memória ou esquecimento dos mortos (Chaumeil 2007; Santos \& Gambim Júnior 2017).

Vemos no registro arqueológico, tanto os que foram aqui especificados quanto o sítio Curiaú Mirim I, dados que apontam muito mais para a memória do que o esquecimento dos mortos. Este último muito difundido na antropologia social para a América do Sul (Carneiro da Cunha 1977; Chaumeil 2007).

Apesar das mudanças culturais que ocorreram ao longo desses anos, vemos, através dos dados arqueológicos acrescidos da etnologia amazônica que esses ornamentos provavelmente faziam parte de uma rede maior de comunicação e de relações nas Guianas (Gallois 2005; Gassón 2000) que só podem ser devidamente compreendidas ao usar todas as possibilidades de evidências de dados disponíveis.

Ao observarmos estes contextos podemos agora começar a observar algumas questões que denotam mobilidades e movimentos de pessoas e objetos, de materiais singulares entre áreas geográficas distantes, assim como o ciclo de vida desses objetos e quais seriam seus 
vínculos e circulações, principalmente quando se referem ao questionamento dos possíveis produtores e também os consumidores.

Os adornos estimulam o exercício de enxergar as pessoas por trás desses objetos, ou os atores sociais envolvidos e integrados aos sistemas sociais das Guianas em suas redes de relações e trocas, marcados pela construção de sociabilidades e das potencias estrangeiras.

Prova da importância que os adornos certamente possuíam, é que foram eternizados nas deposições funerárias e ainda espacialmente demarcados, o que ganha ainda mais sentido devido aos dados contextuais analisados e possibilidades interpretativas da etnografia amazônica.

\section{AGRADECIMENTOS}

Agradeço a CAPES pela concessão de bolsa de auxilio à pesquisa durante o andamento do mestrado que originou este artigo e pela orientação da professora Dra. Cláudia Rodrigues Carvalho (Museu Nacional/UFRJ - PPGArq). À Alexandra e Rafaela, que me auxiliaram durante as análises dos sepultamentos e ao Alan Nazaré que gerou informações referentes à análise cerâmica presentes neste artigo. À professora Dra. Denise Maria Cavalcante Gomes pelos comentários, aos colegas arqueólogos Michel Bueno Flores, Kleber Souza Oliveira, Jelly Juliane Souza de Lima e aos pareceristas deste artigo. E finalmente agradeço à Mariana Cabral e João Saldanha pela oportunidade de estudar o sítio Curiaú Mirim I e outros contextos funerários do Amapá.

\section{NOTAS}

${ }^{1} \mathrm{O}$ que não quer dizer que se neguem os corpos não humanos e o universo das coisas materiais, mas as análises se centraram no corpo visto como um tipo especial de cultura material (Sofaer 2006), logo são considerados tanto os corpos (esqueletos humanos) quanto os artefatos (adornos e urna antropomorfa decorada).

${ }^{2}$ Os dados e parte das interpretações do sítio Curiaú Mirim I, aqui apresentados são referentes à minha dissertação de mestrado intitulada "Corpo, Vida e Morte na foz do rio Amazonas: as estruturas funerárias do sitio Curiaú Mirim I/ AP" defendida em 2016, pelo Programa de Pós Graduação em Arqueologia do Museu Nacional da Universidade Federal do Rio de Janeiro.

${ }^{3} \mathrm{E}$ suas variantes explicações de acordo com as comunidades indígenas observadas.

${ }^{4}$ Como pode ser observado no mapa, e em especifico para este artigo duas estruturas apontadas pelas setas cujos conteúdos e gestos de deposição levam a indagar sobre sua funcionalidade.

${ }^{5}$ Para melhores detalhes ver Gambim Júnior 2016.

${ }^{6}$ Esse poço teste (parte integrante do sítio) é fruto de uma escavação emergencial dista em torno de pouco menos de 100 metros da área posteriormente aberta, que equivale a $1070 \mathrm{~m}^{2}$ de área total escavada por meio do uso de decapagem mecânica.

${ }^{7}$ Serão necessárias mais datações absolutas e mais análises que considerem análise dos solos e arqueobotânica para elucidar se este seria de fato um possível sitio habitação ou um sítio cerimonial, lembrando que os buracos de poste não necessariamente sejam respectivos às unidades domésticas, mas estruturas de outra natureza. 


\section{REFERÊNCIAS}

Abbas, A. R. 2013. Os sepultados de Jabuticabeira II, SC-insights e inferências sobre padrões fenotípicos, análise de modo de vida e organização social através de marcadores de estresse músculo-esqueletal. Tese de Doutorado. Programa de Pós-Graduação em Arqueologia da Universidade de São Paulo, São Paulo.

Barbosa, C. A. P. 2011. As iconografias das urnas funerárias antropomorfas Maracá (Amapá) - A coleção Gruta das Caretas. Dissertação de Mestrado, Programa de Pós-Graduação em Antropologia e Arqueologia da Universidade Federal do Piauí, Teresina.

Barcellos Neto, A. 2012. Objetos de poder, pessoas de prestígio: a temporalidade biográfica dos rituais xinguanos e a cosmopolítica Wauja. Mundo Amazônico n. 3, p. 71-94.

Bel, M. van den. 2015. Archaeological investigations between Cayenne Island and the Maroni river: a cultural sequence of western coastal French Guiana from 5000 BP to present. Tese de doutorado, Universidade de Leiden. Sidestone Press, Leiden.

Boomert, A. 1987. Gifts of the Amazons: Green stone pendants and beads as items of ceremonial exchange in Amazonia and the Caribbean. Antropológica, n. 67, p. 3354. Leiden.

Bourdieu, P. 1977. Outline of a theory of practice. Cambridge University Press, Cambridge.

Braudel, F. 1965. História e ciências sociais: a longa duração. Revista de História, v. 30, n. 62, p. 261-294.

Cabral, M. P. 2014. No tempo das pedras moles: arqueologia e simetria na floresta. Tese de doutorado. Programa de pós-graduação em Antropologia. Universidade Federal do Pará, Belém.
Cavalcante, T. L. V. 2011. Etno-história e história indígena: questões sobre conceitos, métodos e relevância da pesquisa. História, v.30, n.1, p. 349-371. São Paulo.

Capasso, L.; Kennedy, K. A. R.; Wilczak, C. A. 1999. Atlas of occupational markers on buman remains. Edigrafital s.pa, Italy.

Chaumeil, J. 2005. Un método de asimilación. Sobre la noción de transformación en unas culturas sudamericanas. In Chamanismo y sacrificio. Perspectivas arqueológicas y etnológicas en sociedades indígenas de América del Sur, p. 165-176, Bogotá.

2007. Bones, flutes, and the dead: memory and funerary treatments in Amazonia. Time and memory in indigenous Amazonia: Anthropological perspectives, p. 243 283, University Press of Florida, USA.

Coutet, C.; Romon, T.; Serrand, N. 2014. Ossements et perles en coquillage des sépultures précolombiennes de Yalimapo (Awala-Yalimapo). Karapa, vol. 3, juin. Rémire-Montjoly.

Duday, H. 2006. Archaeothanatology or Archaeology of Death. In: Social Archaeology of Funerary Remains. Oxford, Oxbow Books.

Gallois, D. T. 2005. Redes de relações nas Guianas. Editora Humanitas, São Paulo.

Gambim Júnior, A. 2016. Corpo, vida e morte na foz do rio Amazonas: as estruturas funerárias do sítio Curiaú Mirim I/ AP. Dissertação de mestrado. Programa de Pós-Graduação em Arqueologia do Museu Nacional da Universidade Federal do Rio de Janeiro, Rio de Janeiro.

Gambim Júnior, A; Scheffler, S. M.; Sequeira Fernandes, A. C. \& Rodrigues-Carvalho, C. 2017. Crinóides fósseis associados a urnas funeráriais na foz do rio Amazonas (Comunicação). XXV Congresso brasileiro de paleontologia, Ribeirão Preto, SP. No prelo. 
Gassón, R. 2000. Quirípa and Mostacillas: The Evolution of Shell Beads as a Medium of Exchange in Northern South America, Ethnohistory 47(3-4):581-609.

Gomes, D. M. C. 2007. The diversity of social forms in Pre-Colonial Amazonia. Revista de Arqueologia Americana, n. 25, p. 189-225.São Paulo.

2008. Cotidiano e poder na Amazônia pré-colonial. EDUSP/FAPESP.São Paulo.

2010. Os contextos e os significados da arte cerâmica dos Tapajó. In: Pereira, E.; Guapindaia, V. L. C. (Orgs.). Arqueologia amazônica. Belém: Museu Paraense Emílio Goeldi, SECULT, IPHAN, v. 1, p. 213-234. Belém.

2012. O perspectivismo ameríndio e a ideia de uma estética americana. Bol. Mus. Para Emilio Goeldi. Cienc. Hum, p. 133-159. Belém.

2016. O lugar dos grafismos e das representações na arte pré-colonial amazônica. Mana, v. 22, n. 3, p. 671-703.

Guapindaia, V. 2001. Encountering the Ancestors: The Maracá Urns. In: Unknown Amazon. Nature in culture in ancient Brazil. Edited by McEwan, Baretto et Neves. London: British Museum Press.

Hilbert, P. P. 1957. Contribuição à arqueologia do Amapá: Fase Aristé. Boletim do MPEG Antropologia 1, Belém.

Junqueira, C.; Vitti, V. T. O Kwaryp kamaiurá na aldeia de Ipavu. Estudos Avançados, v. 23, n. 65, p. 133-148, 2009.

Lagrou, E. 2007. A fluidez da forma: arte, alteridade e agência em uma sociedade amaz̧ônica (Kaxinawa, Acre). PPGSA-UFRJ.

2012. Caminho da Miçanga: arte e alteridade entre os ameríndios. Enfoques, v. 11, n. 2 .

Lima Guedes, A.P. 1897. Relatório sobre uma Missão Ethnographica e Archeologica aos Rios Maracá e Anauerá-Pucú (Guyana Brazileira). Boletim do Museu Paraense de História Natural e Etnografia, Belém, V.2, n 1.

Lima da Costa, M.; Resque Lopes da Silva, A. C.; Simões Angelica, R. 2002. Muyrakytã ou Muiraquitã, um Talismã Arqueológico em Jade Procedente da Amazônia: uma revisão histórica e considerações antropogeológicas. Acta amazonica, v. 32, n. 3, p. 467-490.

Lima, Jelly Juliane Souza de; Gambim Júnior, Avelino; Silva, Alan Nazaré da; Saldanha João Darcy de Moura. 2014. Práticas de deposição em estruturas negativas na pré-história tardia da costa estuarina do Amapá. II SAB NORTE, Macapá, AP.

Hodder, I. 1987. The contribution of the long term. Archaeology as long-term history, p. 1-8.

Machado, A. L. C. 1997. Museu Paraense Emílio Goeldi. Relatório do Salvamento Arqueológico no Sítio AP-MA-05: Campus Universitário Macapá - AP.

McEwan, C. 2001. Seats of Power. Axiality and Acess to Invisble Worlds. In: Unknown Amazon. Nature in culture in ancient Brazil. Edited by McEwan, Baretto et Neves. London: British Museum Press.

Meggers, B. \& Evans, C. 1957. Archaeological investigations at the mouth of the Amazon. Smithsonian Institution, Bulletin of the Bureau of American Ethnology. 167: 1-664p.

Miller, J. 2007. As coisas: os enfeites corporais e a noção de pessoa entre os Mamaindê (Nambiquara). Tese de Doutorado. Programa de pós-graduação em Antropologia Social do Museu Nacional da Universidade Federal do Rio de Janeiro, Rio de Janeiro.

Nascimento, L. S.; Gambim Júnior, A. 2017. Uma História Indígena De Longa Duração Na Amazônia Antiga: Práticas Funerárias Da Foz Do Rio Amazonas. III Encontro de Discentes de História da UNIFAP. Amapá. 
Nimuendajú, C. 2004. In Pursuit of a past Amazon: archaeological researches in the Brazilian Guyana and in the Amazon region. Elanders Infologistik.

Noelli, F. S. 1996. As hipóteses sobre o centro de origem e rotas de expansão dos Tupi. Revista de antropologia, p. 7-53.

Pesquisadores indígenas do museu Kuahí e Andrade, Ugo M. (org.). 2009. Turé dos Povos Indígenas do Oiapoque. Rio de Janeiro / São Paulo: Museu do Índio, Iepé - Instituto de Pesquisa e Formação em Educação Indígena.

Ramos, A. R. 2012. "The Politics of Perspectivism". Annual Review of Anthropology, 41:481-494.

Rival, L. 2005. Introduction: What Constitutes a Human Body in Native Amazonia? In Tipiti: Journal of the society for the Anthropology of Lowland South America, v. 3, n. 2, p. 1.

Mann, R. W.; Hunt, D. R. 2013. Photographic regional atlas of bone disease: a guide to pathologic and normal variation in the human skeleton. Charles C. Thomas Publisher. Springfield, Illinois, USA.

Rodrigues-Carvalho, C. 2004. Marcadores de estresse ocupacional em populações sambaquieiras do litoral Fluminense. Unpublished. Ph. D. thesis. Escola Nacional de Saúde Pública/ Fiocruz. Rio de Janeiro.

Roth, W. E. 1924. An introductory study of the arts, crafts, and customs of the Guiana Indians. Johnson Reprint Corporation.

Sá Júnior, L. C. 2014. Philipe Descola e a Virada Ontológica na Antropologia. Ilha Revista de Antropologia, v. 16, n.2, p. 07-36, UFSC, Santa Catarina.

Saldanha, J. D. M.; Cabral, M. P. 2012. Projeto de Resgate Arqueológico na Cerâmica João de Barro, Macapá. Nuparq/IEPA, Amapá. Relatório de Campo. Inédito.
Saldanha, J. D. M. 2017. Poços, Potes e Pedras: Uma Longa História Indígena na Costa da Guayana. Tese de doutorado. Programa de pós-graduação em Arqueologia da Universidade de São Paulo, São Paulo.

Saldanha, J. D. M.; Cabral, M. P.; Nazaré, A. S.; Lima, J. J. S.; Flores da Silva, M. B. 2016. Os complexos cerâmicos do Amapá: proposta de uma nova sistematização in Cerâmicas Arqueológicas da Amazônia: Rumo a uma nova sintese. Belém, IPHAN/MPEG.

Scaramelli, F. \& Scaramelli, K. T. 2005. The roles of material culture in the colonization of the Orinoco, Venezuela. Journal of Social Archaeology, v. 5, n. 1, p. 135-168.

Schaan, D. P. 2004. The Camutins chiefdom: rise and development of complex societies on Marajó island, brazilian Amazon. Tese de Doutorado. Pittsburgh: Universidade de Pittsburgh.

2014. Arqueologia para etnólogos: colaborações entre arqueologia e antropologia na Amazônia. Anuário Antropológico, 39, 13-44. UnB, Brasília.

Seeger, A.; da Matta, R.; Viveiros de Castro, E. 1979. A construção da pessoa nas sociedades indígenas brasileiras. In: Oliveira Filho, JP Sociedades indígenas e indigenismo no Brasil. Rio de Janeiro: UFRJ, Marco Zero.

Sofaer, J. R. 2006. The Body as Material Culture: A Theoretical Osteoarchaeology. Cambridge University Press, New York.

Souza, S. M. F. M.; Rodrigues-Carvalho, C. \& Guapindaia, V. 2001. A necrópole Maracá e os problemas interpretativos em um cemitério sem enterramentos. Boletim do Museu Paraense Emilio Goeldi, Belém, 17(2):479-520.

Stodder, A. L.W. \& Palkovich, A. M. 2012. The bioarchaeology of individuals. Gainesville: University Press of Florida, Florida.

Thomas, J. 2002. Understanding the neolitbic. Routledge.London. 
2012. Some deposits are more structured than others. Archaeological Dialogues,19, 124- 127.

2015. The future of archaeological theory. Antiquity, v. 89 , n. 348 , p. $1287-$ 1296.

Turner, T. S. 2012. The social skin. HAU: Journal of Ethnographic Theory, v. 2, n. 2, p. 486-504.

Van Velthem, L. H. 2003. O belo é a fera. A estética da produção da predação entre os Wayana \Assírio \& Alvim - Museu Nacional de Etnologia, Lisboa.

Vidal, L. B. 2007. Povos indígenas do baixo Oiapoque: o encontro das águas, o encruzo dos saberes e a arte de viver. Museu do Índio e IEPÉ.

Viveiros de Castro, E. B. 1979. A fabricação do corpo na sociedade xinguana. Boletim do Museu Nacional, $\mathrm{n}^{\circ}$ 32. Rio de Janeiro. 1986. Araweté: os deuses canibais. Rio de Janeiro, Jorge Zahar Editor.

2002. A inconstância da alma selvagem $e$ outros ensaios de antropologia. São Paulo: Cosac \& Naify. 